This work is licensed under a Creative Commons Attribution 4.0 International License.

Ovaj rad dostupan je za upotrebu pod licencom Creative Commons Imenovanje 4.0 međunarodna.

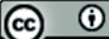

Ivana MARTINOVIĆ

UDK 028(497.5)-053.2

Odsjek za informacijske znanosti

DOI: https://doi.org/10.29162/ANAFORA.v6i2.1

Filozofski fakultet u Osijeku

Lorenza Jagera 9, HR - 31000 Osijek

Izvorni znanstveni članak

imartinovic@ffos.hr

Original Research Article

Ivona GRGIĆ

Primljeno 31. svibnja 2019.

Odsjek za informacijske znanosti

Received: 31 May 2019

Filozofski fakultet u Osijeku

Lorenza Jagera 9, HR - 31000 Osijek

Prihvaćeno 9. listopada 2019.

igrgic@ffos.hr

Accepted: 9 October 2019

\title{
Elizabeta KOTROMANOVIĆ
}

Odsjek za informacijske znanosti

Filozofski fakultet u Osijeku

Lorenza Jagera 9, HR - 31000 Osijek

ekotromanovic@ffos.hr

\section{UŽITAK U ČITANJU: TEME U LITERATURI ZA MLADE OBJAVLJENOJ U HRVATSKOJ 2016. - 2019. GODINE}

Čitanje je važno da bismo odmorili svoje stavove,

ponekad ogorčene na svijet

i našli drugačiju valnu duljinu i povezali se s drugačijim svjetovima i ljudima,

pa tako i osjećajima.

učenik 2. r. strukovne trogodišnje škole 


\section{Sažetak}

Ovaj rad sastoji se od teorijskog i empirijskog dijela. U teorijskom dijelu govori se ponajprije o svrsi čitanja, zatim se raspravlja o rezultatima koje mladi iz Hrvatske pokazuju na međunarodnim ispitivanjima pismenosti te o mogućim uzrocima pojave izostanka čitanja iz užitka kod mladih. Nadalje, govori se o motivima, interesima i navikama mladih na temelju rezultata ranije provedenih istraživanja. Autorice zauzimaju stav da je tema knjige jedan od čimbenika koji mogu potaknuti i motivirati mlade na čitanje. $\mathrm{U}$ radu se nadalje donosi pregled tema koje se pojavljuju u knjigama namijenjenim mladima objavljenim od 60 -ih godina 20 . st. naovamo. $\mathrm{U}$ empirijskom dijelu rada donose se rezultati istraživanja provedenog kombinacijom različitih metodoloških postupaka; stvaranjem popisa knjiga te analizom sadržaja, s ciljem utvrđivanja tema koje se pojavljuju u knjigama za mlade objavljenim u Hrvatskoj u razdoblju od 2016. do travnja 2019. godine. U zaključku istraživanja donose se ponajprije saznanja o tome koje su teme prisutne u knjigama za mlade. Zaključak na kraju rada objedinjuje spoznaje o tematici knjiga za mlade i onih do kojih se došlo temeljem proučavanja prethodnih istraživanja i teorijskih spoznaja o temama čitanja, te ukusima, navikama i interesima mladih za čitanje iz užitka kao i o ulozi tema knjiga u motivaciji mladih za takvu vrstu čitanja.

Ključne riječi: čitanje iz užitka, knjige za mlade, mladi, teme u knjigama za mlade, Hrvatska

\section{Uvod}

„Čitanje je najbolje učenje“ - kaže Puškin, dok primjerice Edmondo de Amicis daje sasvim oprečno određenje čitanja tvrdeći da „čitanje ne znači učenje; čitanje je užitak, a učenje je napor; doista, svi čitaju, a vrlo malo ih uči“. Te premise, iako stare nekoliko stotina godina, vrijede u današnje vrijeme i ne postavlja ih se kontradiktorno, naprotiv, na čitanje se gleda kao na preduvjet učenja, ali i užitak ili bijeg od stvarnosti. Čitanje se proučava u okviru psihologije, neuroznanosti, lingvistike, računalstva, književnosti, informacijskih i drugih područja znanosti. Sva navedena područja nude definiciju čitanja iz drugačije perspektive. Tako se u kognitivnoj znanosti čitanje shvaća kao sposobnost konstruiranja lingvističkoga značenja iz pisanih reprezentacija jezika (usp. Verhoeven, Reitsma, Siegel 2011: 388), dok je u terminologiji teorije informacija prihvaćeno određenje da je čitanje primanje informacija u pisanom obliku (usp. Furlan 1963: 513). U okviru komunikacijske znanosti čitanje se, kao i govor, definira kao vrsta komunikacije (Russell 1951: 274). Desetljećima se vode rasprave oko opisivanja i tumačenja karakteristika procesa čitanja, a mišljenja su i teorije 
oprečne. Proces čitanja opisuje se najčešće kao niz viših kognitivnih procesa: leksičko procesiranje, mapiranje između pravopisa i fonologije, uparivanje rečenica, konceptualne kombinacije itd. (Kennedy, Radach, Heller, Pynte ed. 2010: V; Leinenger 2014). Breznitz (2006) čitanje definira kao kognitivnu aktivnost koja na različitim razinama zahtijeva aktivaciju sustava za procesiranje informacija, uključujući percepciju, pamćenje, procesiranje i output.

Suvremeni pogledi na čitanje podrazumijevaju učenje i zabavu kao osnovnu svrhu čitanja. Tijekom povijesti, svrha i funkcije čitanja mijenjale su se i prilagođavale aktualnim potrebama društva. S obzirom na brzinu kreiranja, protoka i dijeljenja informacija, danas pojedinac mora moći čitati vrlo brzo i prilagođavati se vrlo raznolikom čitateljskom materijalu da bi pravovremeno došao do potrebne, recentne i relevantne informacije ili da bi komunicirao. Istovremeno, da bi mogao razumjeti tekst ili pak uživati u čitanju, današnji čitatelj mora biti kadar sporo čitati, jer „zahtjevniji procesi razumijevanja zahtijevaju tehniku sporoga čitanja. To vrijedi i za užitak u čitanju, jer se tekst koji čitamo s pohlepom i nestrpliivošću opire užitku“" (Pšihistal 2008: 52). U današnje vrijeme osnovnim funkcijama čitanja podrazumijevaju se: obrazovna korist, individualni razvoj, užitak i eskapizam (Tomašević 2008: 223-224). Čitanje je nesumnjivo temelj (samo)obrazovanja i cjeloživotnog učenja i ključ za postizanje akademskih vještina. ${ }^{1}$ Čitanjem pojedinac ostvaruje nebrojene dobrobiti. Osim intelektualnih kapaciteta, čitanjem se proširuju i emocionalni kapaciteti pojedinca. Čitanje je nužna vještina za osobni i društveni razvoj čovjeka. Dobra navika čitanja je zdrava ovisnost; kada djeca ovladaju tom snažnom navikom, ona poboljšava njihov vokabular, analitičke vještine, koncentrirajuću snagu i dešifriranje novih riječi te na taj način pomaže učeniku u njegovim akademskim postignućima (usp. Cunningham \& Stanovich 2001: 138). Stjecanje sposobnosti čitanja osnova su za ispunjenje društvenih i gospodarskih potreba društva u 21. stoljeću (EACEA 2011).

\footnotetext{
${ }^{1}$ Akademske vještine: primjeri akademskih vještina uključuju upravljanje vremenom, time management, sposobnost čitanja, usmenu komunikaciju, pisanu komunikaciju, kritičko mišljenje, istraživačke sposobnosti, analitičko mišljenje i rješavanje problema, organizacijske i interpersonalne vještine. URL: https://www.reference.com/education/examples-academic-skills-fb883ae98e3b3ac4 (24. 5. 2019.).
} 


\section{O (ne)čitanju mladih}

Istraživanje pismenosti PISA (Programme for International Student Assessment) koje svake treće godine na međunarodnoj razini provodi Organizacija za ekonomsku suradnju i razvoj (OECD 2019) među pola milijuna petnaestogodišnjaka iz ukupno sedamdesetak zemalja svijeta donosi neke nove pokazatelje o čitanju u kojima je moguće prepoznati pojavu Matejeva efekta²

Bavljenje čitanjem snažno utječe na čitateljska postignuća. Bolji čitatelji više sudjeluju u čitanju, a rezultat toga je više znanja i razvijenije čitateljske vještine. Učenici koji manje čitaju, smatraju materijale za čitanje preteškima i razvijaju negativne stavove prema čitanju, a time i smanjuju svoje mogućnosti za razvoj strategija čitanja s razumijevanjem. (Stričević 2005: 391)

Navedeno istraživanje pokazuje da učenici iz Hrvatske iz ciklusa u ciklus istraživanja ostvaruju ispodprosječne rezultate i na testiranju prirodoslovne i matematičke, i na testovima čitalačke pismenosti ${ }^{3}$ (usp. OECD 2019). U sagledavanju mogućih uzroka činjenice o izostanku želje i volje za čitanjem mladih ${ }^{4}$ u Hrvatskoj moguće je vratiti se Amicisovoj tvrdnji o čitanju navedenoj na početku ovoga rada, ali u malo drugačijem smislu. Čitanje mladima ne predstavlja užitak jer podsjeća na učenje, stoga predstavlja napor. Međutim, zasigurno postoji velik broj mladih koji čitaju. Većina mladih zapravo voli čitati i pronalazi užitak u čitanju. To potvrđuju i rezultati opsežnog istraživanja čitateljskih navika u okviru znanstvenog projekta Informacijske potrebe $i$ citateljski interesi građana Hrvatske koji govore da 51,3\% učenika voli čitati, a 38,1 \% učenika čita kad mora za školu (Stričević, Jelušić 2010: 26). Za čitanje je, osim dubokog mentalnog angažmana, potrebna i snažna motivacija. Motivacija za čitanje postaje sve češća tema znanstvenih istraživanja u posljednjih 15 godina jer se upravo na motivaciju gleda kao na osnovnu pretpostavku napretka u čitanju i ostvarenje

\footnotetext{
${ }^{2}$ Matejev efekt - prema Evanđelju po Mateju - bogati postaju bogatiji, a siromašni siromašniji. „Doista, onomu koji ima još će se dati, neka ima u izobilju, a od onoga koji nema oduzet će se i ono što ima." (Mt 25: 29)

${ }^{3}$ PISA definira čitalačku pismenost kao sposobnost razumijevanja, korištenja i promišljanja o tekstovima te angažiranosti $u$ čitanju tekstova radi postizanja osobnih ciljeva, razvoja vlastita znanja $i$ potencijala te aktivnog sudjelovanja $u$ društvu. (OECD 2019)

${ }^{4}$ Kako se pojam mladi, tinejdžeri, adolescenti u literaturi vrlo različito i vrlo široko definiraju i određuju dobne granice osoba koje ti pojmovi podrazumijevaju, za potrebe ovoga rada termin mladi podrazumijeva osobe u dobi između 13 i 19 godina.
} 
svih elemenata koji su u osnovi vještine čitanja (Čudina Obradović 2014: 252). Intrinzična motivacija za čitanje igra snažnu ulogu u određivanju hoće li i koliko djeca čitati iz užitka u slobodno vrijeme (Troyer et al. 2019: 1198). Motivacija za čitanje jedan je od bitnih elemenata za aktivno uključivanje osobe već u ranoj dobi u proces čitanja (Morgan \& Sideridis 2006; Strommen \& Mates 2004 prema Ciampa 2012: 2). Miljković naglašava da bi djeci umjesto nametanja određenih knjiga trebalo ponuditi one sadržaje i teme koje ih zanimaju da bi se povećala njihova motivacija za čitanje (Miljković prema Kotarac 2011).

Čitateljske navike i interesi mladih mijenjaju se. Do spoznaja o tome što mladi žele čitati, kada i koliko čitaju, dolazi se istraživanjem njihovih čitateljskih navika i interesa. Takva se istraživanja provode u okviru psihologije, pedagogije u okviru istraživanja o načinima provođenja slobodnog vremena djece i mladih, zatim informacijskih znanosti u okviru navika korištenja knjižnice te potreba i interesa korisnika, a najčešće je povod takvih istraživanja pojava novog medija ili kad pod utjecajem nekog drugog medija knjiga padne u drugi plan.

\section{3. Čitateljski ukusi, navike i interesi mladih}

Određivanju čitateljskih ukusa, interesa i navika mladih potrebno je posvetiti posebnu pozornost jer to omogućuje ispravno usmjeravanje i savjetovanje $u$ tome što odabrati za čitanje, a to pak može izravno utjecati na njihove čitateljske navike.

U Hrvatskoj se istraživanja čitateljskih navika i interesa intenzivnije počinju provoditi 60-ih godina 20. st., tj. nakon pojave televizije. Sabolović-Krajina objedinila je rezultate istraživanja o navedenoj temi u razdoblju između 1987. i 1993. godine među tinejdžerima (13 - 19 godina starosti) te došla do zaključaka da su mladi u to vrijeme čitali iz potrebe za čitanjem, a ne zbog obaveze ili prisile. Beletristika je bila najčitanija vrsta literature; mladi tinejdžeri davali su prednost književnosti za djecu i mlade. Prema žanru, najpopularnije su bile pustolovne, detektivske i ljubavne priče, zatim popularno-znanstvena literatura, dok je poezija bila na periferiji čitateljskih interesa tinejdžera. Nadalje, većina djevojaka (73\%) daje prednost čitanju knjiga, dok dječaci više vole čitati stripove (76 \%). Do današnjeg vremena provedeno je još dosta međusobno neovisnih istraživanja čitateljskih navika i interesa mladih, najčešće u okviru diplomskih i završnih radova na različitim fakultetima u Hrvatskoj. Ta istraživanja najčešće nisu objavljena. Nema istraživanja provedenih na nacionalnoj razini ili takvih koja bi 
rasvjetljavala širi kontekst pismenosti i čitanja mladih u Hrvatskoj. U studiji koju je askGfK proveo 2017. o tržištu knjiga navodi se, primjerice, da $62 \%$ mladih u dobi do 24 godine čita knjige više od prosjeka (askGfK 2017). Takve rezultate potrebno je promatrati obazrivo iz razloga što je nepoznata metodologija kojom je istraživanje provedeno te su, konkretno u ovom primjeru, vrlo nejasno i široko definirane kategorije ispitanika. U odnosu na to, nemoguće je donositi zaključke o čitanju mladih na temelju tih podataka.

Godine 2004. objavljeni su rezultati istraživanja čitateljskih navika, interesa i svjetonazora mladih provedenog na uzorku od 717 mladih u dobi od 15 do 18 godina u Osječko-baranjskoj i Vukovarsko-srijemskoj županiji koji pokazuju da mladi osim lektirnih naslova čitaju i literaturu vezanu uz probleme mladih, npr. rješavanje problema ovisnosti ili knjige iz područja popularne psihologije ili duhovne literature za mlade. Autorica navodi da je pri izboru naslova prevladao sadržajno-tematski žanrovski kriterij te da mladi čitaju knjige koje su na ljestvicama čitanosti ili su popularne među mladima ili one koje su dobile filmsku inačicu (usp. Vodopija 2004: 116-117). U jednom kvalitativnom istraživanju na tu temu provedenom u novije vrijeme, 2016., u okviru neobjavljenog diplomskog rada, na 20 mladih ispitanika pokazuje se da je 16 ispitanika navelo roman kao svoju omiljenu književnu vrstu. Uz roman, četiri su ispitanika navela novelu i pripovijetku kao literaturu koju vole. Dva su ispitanika navela da čitaju poeziju, jedan dramu i jedan strip. U odnosu na omiljene žanrove, ispitanici vole literaturu iz područja fantastike, znanstvene-fantastike, zatim biografske, kaubojske, kriminalističke, povijesne i psihološke romane (Peroš 2016: 54).

Ti rezultati ne razlikuju se mnogo od rezultata koje donose istraživanja čitateljskih interesa mladih drugdje u svijetu. Tako primjerice istraživanje provedeno u Delhiju (Walia i Sinha 2014) na uzorku od 224 mladih u dobi između 12 i 18 godina pokazuje da najviše mladih preferira beletristiku (41,7 \%), a potom publicistiku (34,1\%). Kad se govori o preferencijama u odnosu na žanrove, rezultati navedenog istraživanja pokazuju da mladi najviše vole čitati trilere (35,9\%), zatim horor književnost $(22,4 \%)$ i romantična djela $(18,4 \%)$.

U jednom norveškom istraživanju na uzorku od 212 mladih u dobi između 12 i 15 godina (usp. Tveit 2012) pokazalo se da su mladići (28 \%) zainteresiraniji za publicistiku negoli djevojke (14\%). Mladići vole čitati o povijesti i sportu, a djevojke o slavnim osobama (engl. celebrity). One vole čitati dramatične ljubavne priče u kojima uloge imaju hrabre, emotivne junakinje. Dječaci preferiraju 
akcijske trilere. Istraživanje provedeno u Turskoj među 2372 učenika u dobi od 15 i 16 godina (usp. Kutay 2014) donosi rezultate o tome da je avanturistički roman omiljeni žanr među mladim djevojkama (75 \%) i mladićima (72,6 \%). Sljedeći su žanrovi koje djevojke preferiraju romantična djela (70 \%), zatim horori $(52,2 \%)$ i komedije $(49,3 \%)$ te kriminalističko-detektivske priče (40,2 \%). Mladići preferiraju ratno-špijunske priče (engl. war-spy stories) (56 \%) i kriminalističko-detektivske priče (45 \%) (usp. Kutay 2014: 97-99).

Ti rezultati o vrsti literature, žanrovima i tematici koju mladi preferiraju pri odabiru literature za čitanje iz užitka potvrđuju da mladi vole čitati sve ono što im omogućuje i pomaže odmaknuti se od školskih obaveza i uživati u tekstu.

Čak $69 \%$ mladih u dobi od 12 do 14 godina i $65 \%$ mladih u dobi od 15 do 17 godina izjavljuje da bi čitali više kad bi mogli pronaći više knjiga koje ih zanimaju (Kids and Family Reading Report 2015: 48). Mladi često izjavljuju da ne čitaju zato što imaju poteškoća u pronalaženju ili uopće ne mogu pronaći knjigu koja im se sviđa. Gledajući iz perspektive odrastanja i čitateljskog sazrijevanja, mladićima je za dobro razumijevanje teksta važno da im tema bude zanimljiva, dok djevojke lako čitaju i one tekstove koji im nisu zanimljivi (usp. Rončević Zubković 2005: 36). Mladi vrlo često odabiru knjige u kojima čitajući uživaju i njihovi vršnjaci (usp. Hopper 2005: 118). Osim pristupa istraživanju čitateljskih ukusa, navika i interesa mladih čitatelja na općenitoj razini, Bamberger naglašava individualni pristup. On smatra da svakoj mladoj osobi treba pristupiti individualno i odrediti kojem čitalačkom tipu pripada (usp. Bamberger 1975: 18-19). Tipologiju čitatelja oblikovao je uzimajući u obzir tehniku čitanja, namjeru čitanja te sklonost određenoj vrsti materijala za čitanje te odredio tipa čitatelja: romantični, realistični, estetski i intelektualni. Romantični tip čitatelja voli čarobno i čudesno u djelima. Realističan tip sasvim je obrnutog ukusa od romantičnog. On ne voli ništa s prizvukom fantastike. Intelektualni tip traži objašnjenja i razloge, u pričama traži moralnu komponentu ili praktičnu korist. Estetski tip čitatelja voli zvuk riječi, ritam i rimu, sklon je čitanju i zapamćivanju poezije. Voli zapisivati lijepe dijelove teksta i često iznova čita istu knjigu. Bamberger (1975) naglašava da su rijetki čisti tipovi, odnosno da postoje brojne kombinacije tipova čitatelja. Određivanje tipa čitatelja sastoji se, dakle, od promatranja stava koji mlada osoba zauzima u odnosu prema knjizi.

Moguće je zaključiti da je izuzetno važno ono što mladi imaju na raspolaganju za čitanje iz užitka jer će u toj ponudi tražiti i pronalaziti ili ne pronalaziti 
ono što im pričinjava zadovoljstvo i užitak. S druge strane, promatrajući iz perspektive knjige i autora, za njihov opstanak važno je da knjige budu čitane. „Preživljava ona književnost u kojoj će čitatelji pronaći užitak." (Pšihistal 2008: 54)

U središtu čitateljskih interesa mladeži ponajprije su teme kao što su odnosi među ljudima, osobito odnosi među spolovima i među vršnjacima, problemi koji se javljaju u školi i u obitelji, napose problemi koji obuhvaćaju sve dobne skupine kao što su alkohol, pušenje i droga, danas sve izrazitije nasilje prema drugome i prema sebi. Može se reći da tamne strane života prestaju biti tabu-teme u književnosti. Književnost je uvijek medij u kojem mladi traže i pokušavaju pronaći odgovore na mnoga pitanja. Međutim, današnji tempo života omogućuje sve manje vremena, volje i strpljenja čitatelju za dugotrajna čitanja, iščitavanja i prečitavanja (usp. Hopper 2005: 118; Visinko 2008). Motivacija mladih za čitanje povećava se podudaranjem tematike djela koja se njima namjenjuju i interesa mladih. Upravo je tematika čimbenik prema kojem se djela adolescentske književnosti ili književnosti za mlade razlikuju od djela koja pripadaju dječjoj književnosti ili literaturi namijenjenoj odraslima.

\section{Mijene u tematici knjiga za mlade}

U Europi se literatura namijenjena mladima sve više počinje stvarati 60 -ih godina 20. st. Od tada do današnjeg vremena tematika koja se javlja u djelima vrlo je raznolika. Tako su 70-ih godina u literaturi prisutne sljedeće teme: zagađenje okoliša, ženska emancipacija, rasna diskriminacija, solidarnost s Trećim svijetom. Može se primijetiti da u literaturi više ne postoje tabu-teme kao u ranijem razdoblju. Sve se češće tako pišu romani na temu seksa, bolesti, razvoda braka i smrti (usp. Težak 1998: 10). Osamdesetih godina i dalje su prisutna djela slične tematike, ali se napuštaju klasični oblici romana i stvaraju se neobičniji književni oblici ispreplitanjem žanrova i pripovjedačkih tehnika, rušeći granicu između poezije i proze.

U devedesetima nastavlja se isto, nema tabua i pišu se svi književni oblici. Dominiraju teme kao što su strah, nasilje, kriminal, smrt, maloljetnička prostitucija, SIDA, droga, politička previranja u istočnoj Europi i njihove posljedice na život mladih (usp. Težak 1998: 10).

U Hrvatskoj se u tom razdoblju pojavljuje mnogo djela za djecu i za mlade ratne, ali i fantastične tematike (usp. Zima 1998; Zalar 1998). Zapravo, hrvatska 
je adolescentska književnost u tematskom smislu uhvatila korak sa svjetskim trendovima tek u devedesetima, a i u prvoj polovici 2000. još su uvijek bile zanimljive tabu-teme i autorima, i čitateljima (Zima 2008). Na prijelazu iz 20. u 21. stoljeće i dalje se i u drugim zemljama svijeta i u Hrvatskoj u književnosti zadržava prisutnost tabu-tema u knjigama za mlade, odnosno, prisutne su „teške“ i kontroverzne teme, ili bolje reći, nema tabua, piše se o svemu što se nekad smatralo tabuom (Gruić, Škuflić Horvat 2016: 219). Postavlja se pitanje uspijevaju li autori knjiga za mlade pogoditi čitateljske interese i potrebe mladih za koje pišu i u kojoj mjeri.

Često se o trendovima, pojavama u literaturi piše s većim vremenskim odmakom. Pogledom unatrag i okretanjem iza sebe dolazi se do zapažanja, rezimea i zaključaka o pojavama i specifičnostima vezanim za razdoblje i pravce u književnosti. Jednako tako, važno je pratiti i bilježiti aktualne pojave i bilježiti zapažanja kako bi shvaćanja i pogledi na problematiku bili što obuhvatniji. To je važno činiti i zato da bi se mlade moglo upoznati s literaturom koja je prisutna, da bi mladi mogli pronaći i izabrati ono što ih zanima, što žele i ono što traže.

U empirijskom dijelu ovoga rada donosi se istraživanje tema prisutnih u knjigama za mlade objavljenima u razdoblju od 2016. do travnja 2019. u Hrvatskoj.

\section{Teme novih knjiga za mlade: istraživanje}

Istraživanje tematike koja se pojavljuje u knjigama za mlade objavljenima u Hrvatskoj u razdoblju od 2016. do travnja 2019. godine provedeno je sa svrhom donošenja pregleda djela po temama koji će poslužiti za daljnja istraživanja u različitim znanstvenim područjima te kao podloga za smjernice primjerice učiteljima, profesorima, knjižničarima i nakladnicima u njihovu radu, konkretno u onome dijelu koji se veže za područje knjige za mlade.

\subsection{Metodologija}

Istraživanje se provodilo tijekom studenog i prosinca 2018. te od siječnja do travnja 2019.

\section{Cilj}

Cilj je istraživanja donijeti pregled tema prisutnih u knjigama za mlade objavljenima u Hrvatskoj u razdoblju od 2016. do travnja 2019. godine te pre- 
gled djela u kojima se pojavljuju. U ostvarivanju navedenog cilja pošlo se od sljedećih dvaju istraživačkih pitanja:

- Koje su knjige za mlade objavljene u Hrvatskoj u razdoblju od 2016. do travnja 2019. godine?

- Koje su teme zastupljene u knjigama za mlade objavljenim u Hrvatskoj u razdoblju od 2016. do travnja 2019. godine?

\section{Uzorak}

Do uzorka koji čini popis knjiga namijenjenih mladima objavljenih u Hrvatskoj od 2016. do travnja 2019. godine došlo se pregledavanjem mrežnog kataloga knjiga nakladnika (Lumen izdavaštvo, Mozaik knjiga, Verbum, Naklada Ljevak, Hrvatsko društvo književnika za djecu, Znanje, Profil, Alfa, Despot infinitus, VF Libris, Fokus komunikacije, Algoritam, Studio tim, Salesiana, Figulus, Kršćanska sadašnjost, Naklada Benedikta, Logos Daruvar, Glas Koncila, Kristofori, Harper Collins, Hachette UK, Školska knjiga, Naklada Val, Vorto Palabra, Bookglobe, Semafora, Egmont, Mitopeja, Umjetnička organizacija Knjigohvat, V.B.Z. i Naklada Bošković) te uvidom u računalni knjižnični katalog namijenjen javnosti (OPAC) Gradske knjižnice Zagreb i Gradske i sveučilišne knjižnice u Osijeku. Dakle, u katalogu nakladnika i knjižničnom katalogu tražene su knjige koje pripadaju „knjigama za mlade“.

\section{Postupak}

Pregledavani su katalozi najvećih nakladnika u Hrvatskoj te manjih nakladnika u čijim je mrežnim katalozima knjiga omogućeno pretraživanje knjiga po filtrima:

- godina izdanja,

- kategorija kojoj pripada (književnost za mlade, knjige za mlade, knjiga za mladež).

Isti postupak proveden je u mrežnim katalozima knjižnica. Nakon što je napravljen detaljan popis knjiga, pristupilo se svrstavanju knjiga po predmetnim odrednicama koje su dodijelile knjižnice. Predmetne odrednice pronađene su u mrežnom katalogu knjižnice GISKO, u detaljnom pregledu bibliografskih podataka djela pod kategorijom: predmetnice. Podrijetlo autora utvrđivalo se na temelju imena i prezimena. 


\section{Rezultati i diskusija}

\section{Broj objavljenih knjiga}

Od 123 djela pronađena u mrežnim katalozima nakladnika koja su namijenjena mladima, najveći broj, točnije njih 43,9 \%, objavljeno je 2018. Zatim, 2017. $28,46 \%, 2016.20,33 \%$ te u 2019. (od siječnja do travnja) 7,31 \% kao što je prikazano na Slici 1. Rezultati pokazuju porast produkcije djela za mlade iz godine u godinu.

$$
\text { 2016. } \square 2017 . \quad \text { 2018. } 2019 .
$$

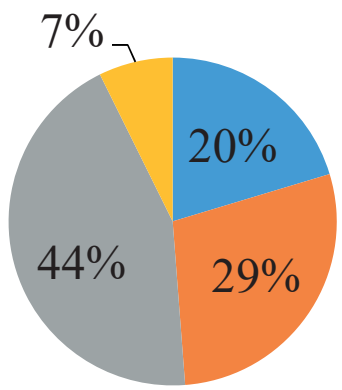

Slika 1. Udio knjiga za mlade u odnosu na godinu izdavanja

\section{Knjige po vrsti}

Po vrsti djela najviše je romana - $89(72,36 \%)$ - zatim priručnika/vodiča/ savjetnika 12 (9,76 \%). Nadalje, 9 djela (7,40 \%) napisano je u obliku zbirke priča/poezije/svjedočanstava, 4 stripa $(3,25 \%)$, dva scenarija (1,63 \%) te dvije slikovnice (1,63\%). Udio ostalih vrsta u koje su svrstane enciklopedija, igrokaz, Biblija i esej iznosi 3,25\%. 


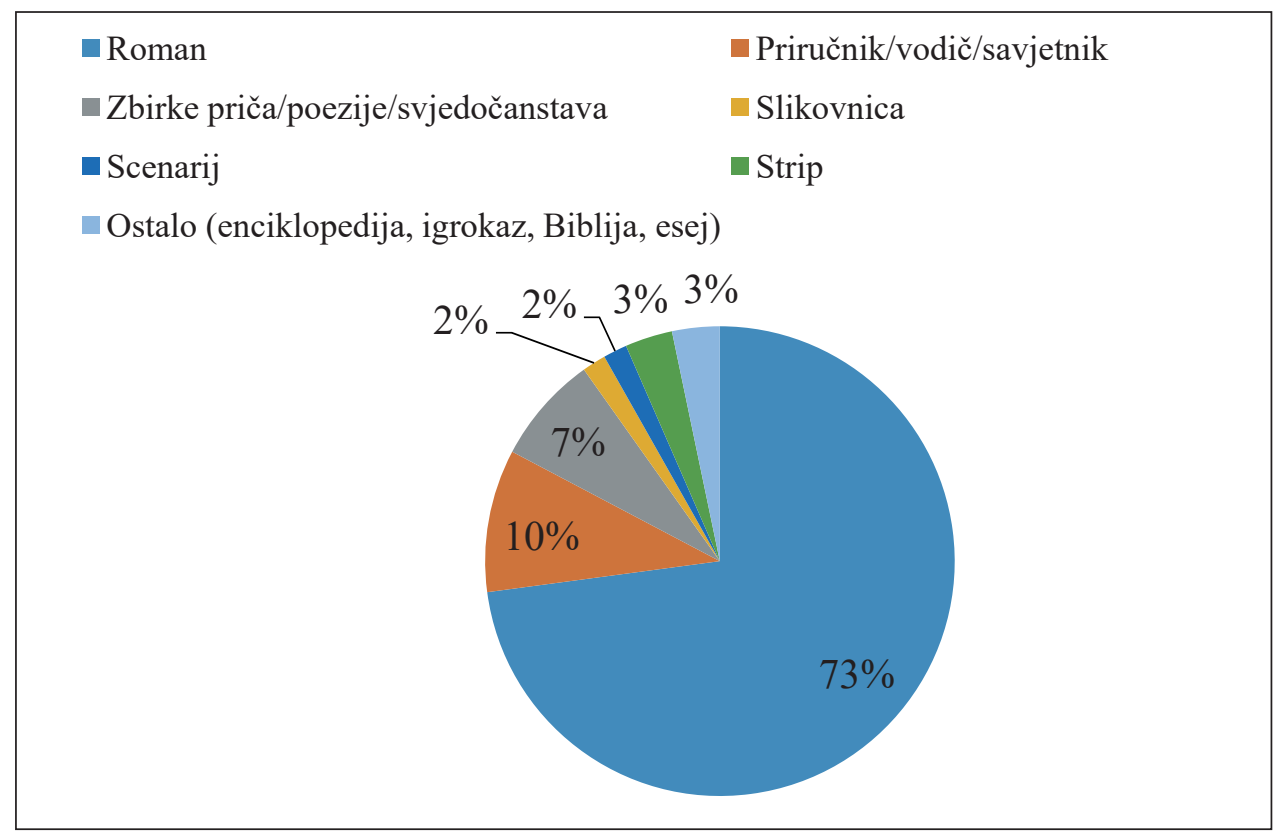

Slika 2. Broj knjiga za mlade po vrstama djela

\section{Autori i nakladnici knjiga}

Podrijetlo autora određeno je prema imenu i prezimenu autora. Shodno tome, strani autori, prema podrijetlu, čine većinu, točnije njih 90 (73,17 \%). Knjiga koje potpisuju domaći autori značajno je manje, tj. 33 (26,83\%).

U istraživanje su uključena ukupno 32 nakladnika. Najviše je knjiga za mlade objavilo Lumen izdavaštvo (13,8 \%), slijedi Verbum (12,2 \%), Mozaik knjiga (11,38 \%), Naklada Ljevak (8,94 \%), Znanje (6,5 \%), Hrvatsko društvo književnika za djecu (5,7 \%), Profil (4,88 \%) te Alfa (4,06 \%). Ostali nakladnici (ukupno $32,52 \%$ knjiga) objavili su svaki jednu do dvije knjige namijenjene mladima, a to su Despot infinitus, VF Libris, Fokus komunikacije, Algoritam, Studio tim, Salesiana, Figulus, Kršćanska sadašnjost, Naklada Benedikta, Logos Daruvar, Glas Koncila, Kristofori, Harper Collins, Hachette UK, Školska knjiga, Naklada Val, Vorto Palabra, Bookglobe, Semafora, Egmont, Mitopeja, Umjetnička organizacija Knjigohvat, V.B.Z. i Naklada Bošković. 
Lumen izdavaštvo

- Mozaik knjiga

Znanje

- Profil

Ostalo
Verbum

Naklada Ljevak

- Hrvatsko društvo književnika za djecu i mlade Alfa

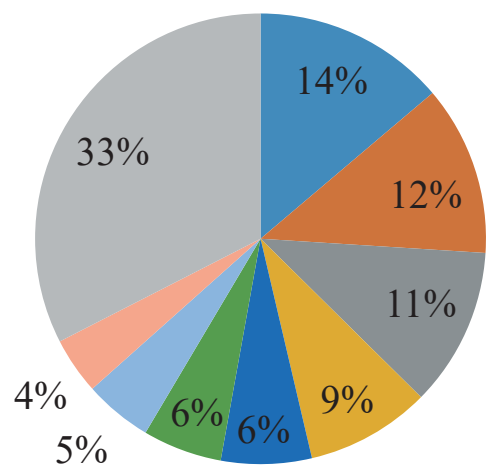

Slika 3. Nakladnici

\section{Teme}

Budući da ne postoji publikacija objavljena na hrvatskom jeziku koja bi objedinjavala sve vrste i žanrove te tematsko-sadržajne aspekte koje obuhvaća aktualna literatura za mlade domaćih autora objavljenih u Hrvatskoj te zato što je broj knjiga za mlade objavljenih u Hrvatskoj stranih autora mnogo veći negoli domaćih autora, u svrstavanju djela u kategorije i potkategorije te $\mathrm{u}$ analizama tematske razine knjiga, autorice ovoga rada, kao polazištem u oblikovanju prilagođene podjele služile su se tematskim vodičem Tematic Guide to Young Adult Literature autorice Alice Trupe.

Knjige za mlade u ovom su istraživanju grubo podijeljene $u$ osam glavnih kategorija: fantastična djela (među kojima su i djela znanstvene fantastike te mitološka, animalistička i bajkovita djela), realistična djela (među kojima su djela koja se bave problemima obitelji, društva te unutarnjim problemima pojedinaca), ljubavna djela, povijesna djela, religijska djela, kriminalistička djela i trileri, pustolovna djela i ostala djela (kategorija djela među kojima su djela koja je prema predmetnoj odrednici knjižnice bilo teško svrstati u neku od drugih kategorija - humoristična djela, djela o općem znanju, pojednostavljeni tehnološki priručnici i sl.). 


\section{A) Fantastična, bajkovita, animalistička i mitološka djela}

Djela fantastične tematike donose priče o nepostojećem. Kathryn Hume donosi jednostavnu definiciju u kojoj fantastiku opisuje kao „svako odvajanje od postojeće stvarnosti, svako kršenje onoga što smatramo fizičkim činjenicama“ (usp. Hume prema Zima 1998: 42). U svijetu koji poznajemo ili potpuno novom, izmišljenom, dogodi se nešto što nije moguće objasniti poznatim zakonima. Na čitateljima je da odluče hoće li se tom novom (ili drugačijem) svijetu nadnaravnih djela prepustiti ili će ga, kao mnogi raniji književni teoretičari, proglasiti mračnom stranom prave, nefantastične književnosti. Ipak, druga polovica 20. stoljeća donosi fantastičnoj književnosti ravnopravnost s drugim žanrovima. Nekolicina stručnjaka (usp. Zima 1998: 42) složila se da, od tri elementa potrebna za književnu interakciju - autor, djelo i čitatelj - za fantastičnost je presudan upravo čitatelj. Fantastika može imati različite oblike. Radnje u nekim nadnaravnim djelima smještene su u zamišljenoj prošlosti ili budućnosti; neke se fokusiraju na magiju i moći te magične ljude i bića; neke opisuju mjesta koja nisu dostupna iz nama poznatog svijeta (usp. Zima 1998: 42). Dakle, od prikazivanja distopijske ili utopijske budućnosti civilizacija, preko vampira, vještica, zombija i vukodlaka, do potpuno novih svjetova i kultura nedostupnih čitateljima - svaka od tih tema može biti i jest obuhvaćena u mnogim nadnaravnim djelima, koja su, kako je pokazalo istraživanje, najzastupljenija u literaturi za mlade izdanoj u Hrvatskoj od 2016. do 2019. U nastavku se navode naslovi djela i njihovi autori koji su u tom razdoblju objavljeni - neki potpuno novi, a neki pak objavljeni davno i zbog trenutačne potražnje objavljeni u novom izdanju. U tim djelima prevladava element fantastičnog, to su: fantastika, znanstvena fantastika, animalistička i mitološka djela, a prikazana su u Tablici 1. 
Tablica 1. Fantastična, bajkovita, animalistička i mitološka djela

\begin{tabular}{|c|c|c|c|c|c|}
\hline $\begin{array}{l}\text { Naslov knjige } \\
\text { i autor }\end{array}$ & $\begin{array}{l}\text { Predmetna } \\
\text { odrednica } \\
\text { knjižnice }\end{array}$ & $\begin{array}{l}\text { Godina } \\
\text { izdanja }\end{array}$ & $\begin{array}{l}\text { Vrsta } \\
\text { djela }\end{array}$ & $\begin{array}{l}\text { Tematska obilježja } \\
\text { djela }\end{array}$ & Nakladnik \\
\hline $\begin{array}{l}\text { Harry Potter i } \\
\text { ukleto dijete: } \\
\text { prvi i drugi } \\
\text { dio - J. K. } \\
\text { Rowling, Jack } \\
\text { Throne, John } \\
\text { Tiffany }\end{array}$ & $\begin{array}{l}\text { Drame -- En- } \\
\text { gleska književ- } \\
\text { nost } \\
\text { Bajkovite dra- } \\
\text { me -- Engleska } \\
\text { književnost }\end{array}$ & 2016. & Scenarij & $\begin{array}{l}\text { Magija, putovanje u } \\
\text { prošlost da bi ju se } \\
\text { promijenilo. }\end{array}$ & Algoritam \\
\hline $\begin{array}{l}\text { Šešir od sno- } \\
\text { va - Snježana } \\
\text { Babić Višnjić }\end{array}$ & $\begin{array}{l}\text { Bajkovite priče } \\
\text {-- Hrvatska } \\
\text { književnost } \\
\text { Humorističke } \\
\text { priče -- Hrvat- } \\
\text { ska književnost }\end{array}$ & 2016. & $\begin{array}{l}\text { Zbirka } \\
\text { priča }\end{array}$ & $\begin{array}{l}\text { Samopouzdanje i } \\
\text { kontrola vlastitih } \\
\text { koraka u životu kroz } \\
\text { motiv čarobnog še- } \\
\text { šira. }\end{array}$ & $\begin{array}{l}\text { Hrvatsko } \\
\text { društvo } \\
\text { književnika } \\
\text { za djecu i } \\
\text { mlade }\end{array}$ \\
\hline $\begin{array}{l}\text { Moj brat živi } \\
\text { u kompjutoru: } \\
\text { vježbaonica } \\
\text { za izgublje- } \\
\text { ne osjećaje } \\
\text { - Branka Pri- } \\
\text { morac }\end{array}$ & \begin{tabular}{|l|} 
Fantastični \\
roman -- Hrvat- \\
ska književnost \\
Humoristički \\
roman -- Hrvat- \\
ska književnost
\end{tabular} & 2016. & Roman & $\begin{array}{l}\text { Radnja smještena u } \\
\text { 2071. godini, prepu- } \\
\text { na opisa tehnoloških } \\
\text { čuda. }\end{array}$ & ALFA d.d. \\
\hline $\begin{array}{l}\text { Šešir pun neba } \\
\text { - Terry Prat- } \\
\text { chett }\end{array}$ & \begin{tabular}{|l|} 
Fantastični ro- \\
man -- Engleska \\
književnost
\end{tabular} & 2017. & Roman & $\begin{array}{l}\text { Razne fantastične i } \\
\text { satirične teme; po- } \\
\text { stajanje vješticom; } \\
\text { borba vještica i vilin- } \\
\text { ske kraljice. }\end{array}$ & $\begin{array}{l}\text { Lumen } \\
\text { izdavaštvo }\end{array}$ \\
\hline $\begin{array}{l}\text { Baklja u noći - } \\
\text { Sabaa Tahir }\end{array}$ & \begin{tabular}{|l|} 
Fantastični ro- \\
man -- Američ- \\
ka književnost
\end{tabular} & 2017. & Roman & $\begin{array}{l}\text { Distopijski svijet, } \\
\text { pokušaj izbavljenja } \\
\text { brata glavnog žen- } \\
\text { skog lika iz zatvora; } \\
\text { smrt, okrutnost, } \\
\text { borba, izdaja. }\end{array}$ & $\begin{array}{l}\text { Lumen } \\
\text { izdavaštvo }\end{array}$ \\
\hline $\begin{array}{l}\text { Grimizna kra- } \\
\text { ljica - Victoria } \\
\text { Aveyard }\end{array}$ & $\begin{array}{l}\text { Fantastični ro- } \\
\text { man -- Američ- } \\
\text { ka književnost }\end{array}$ & 2017. & Roman & $\begin{array}{l}\text { Nadnaravne moći, } \\
\text { borba za pomoć nei- } \\
\text { maštini u obitelji; rat. }\end{array}$ & Znanje \\
\hline $\begin{array}{l}\text { Između dva } \\
\text { svijeta - A. G. } \\
\text { Howard }\end{array}$ & $\begin{array}{l}\text { Fantastični ro- } \\
\text { man -- Američ- } \\
\text { ka književnost } \\
\text { Ljubavni roman } \\
\text {-- Američka } \\
\text { književnost } \\
\end{array}$ & 2017. & Roman & $\begin{array}{l}\text { Spašavanje vlastite } \\
\text { obitelji, zemlja ču- } \\
\text { desa, nadnaravne } \\
\text { sposobnosti. }\end{array}$ & $\begin{array}{l}\text { Lumen } \\
\text { izdavaštvo }\end{array}$ \\
\hline
\end{tabular}




\begin{tabular}{|c|c|c|c|c|c|}
\hline $\begin{array}{l}\text { Ludi svijet - A. } \\
\text { G. Howard }\end{array}$ & \begin{tabular}{|l|} 
Fantastični ro- \\
man -- Američ- \\
ka književnost \\
Ljubavni roman \\
-- Američka \\
književnost
\end{tabular} & 2017. & Roman & $\begin{array}{l}\text { Pronalaženje ravno- } \\
\text { teže između mraka } \\
\text { i svjetla, stvarnosti i } \\
\text { fantazmagorije, iz- } \\
\text { među pravog života i } \\
\text { Zemlje čudesa. }\end{array}$ & $\begin{array}{l}\text { Lumen } \\
\text { izdavaštvo }\end{array}$ \\
\hline $\begin{array}{l}\text { Ureži znak } \\
\text { smrti - Vero- } \\
\text { nica Roth }\end{array}$ & $\begin{array}{l}\text { Fantastični ro- } \\
\text { man -- Američ- } \\
\text { ka književnost }\end{array}$ & 2017. & Roman & $\begin{array}{l}\text { Priča o zanemariva- } \\
\text { nju razlika i starih } \\
\text { sukoba te o udru- } \\
\text { živanju suparnika } \\
\text { koji zajedno nastoje } \\
\text { preživjeti. }\end{array}$ & $\begin{array}{l}\text { Naklada } \\
\text { Ljevak }\end{array}$ \\
\hline $\begin{array}{l}\text { Šampion - } \\
\text { Marie Lu }\end{array}$ & $\begin{array}{l}\text { Fantastični ro- } \\
\text { man -- Američ- } \\
\text { ka književnost }\end{array}$ & 2017. & Roman & $\begin{array}{l}\text { Priča o kušnjama } \\
\text { glavnih likova koji } \\
\text { su nakon prva dva } \\
\text { romana stekli visoke } \\
\text { položaje u Republici. }\end{array}$ & $\begin{array}{l}\text { Lumen } \\
\text { izdavaštvo }\end{array}$ \\
\hline $\begin{array}{l}\text { Blistave visine } \\
\text { - Katharine } \\
\text { McGee }\end{array}$ & \begin{tabular}{|l|} 
Suvremeni ro- \\
man -- Američ- \\
ka književnost \\
Humoristički \\
roman -- Ame- \\
rička književ- \\
nost \\
\end{tabular} & 2017. & Roman & $\begin{array}{l}\text { Radnja u New Yorku, } \\
\text { 2118. godine - raz- } \\
\text { doblje ogromnih } \\
\text { tehnoloških čuda i } \\
\text { podjele društva pre- } \\
\text { ma izgledu, starosti i } \\
\text { bogatstvu. }\end{array}$ & $\begin{array}{l}\text { Profil knji- } \\
\text { ga d.o.o. }\end{array}$ \\
\hline $\begin{array}{l}\text { Pax - Sara } \\
\text { Pennypacker }\end{array}$ & \begin{tabular}{|l|} 
Animalistički \\
roman -- Ame- \\
rička književ- \\
nost \\
Društveni ro- \\
man -- Američ- \\
ka književnost
\end{tabular} & 2017. & Roman & $\begin{array}{l}\text { Snažna povezanost } \\
\text { dječaka i lisca (Pax); } \\
\text { teme o ljubavi i gu- } \\
\text { bitku, prirodi, slobo- } \\
\text { di i traženju sebe. }\end{array}$ & $\begin{array}{l}\text { Lumen } \\
\text { izdavaštvo }\end{array}$ \\
\hline $\begin{array}{l}\text { Mačak s četvr- } \\
\text { tog kata - Vla- } \\
\text { do Rajić }\end{array}$ & \begin{tabular}{|l|} 
Animalistički \\
roman -- Hrvat- \\
ska književnost \\
Humoristički \\
roman -- Hrvat- \\
ska književnost
\end{tabular} & 2017. & Roman & $\begin{array}{l}\text { Život mačka koji je } \\
\text { kao mali napušten i } \\
\text { pronalazi dragu i ve- } \\
\text { selu obitelj; važnost } \\
\text { strpljenja, postupne } \\
\text { prilagodbe, toleran- } \\
\text { cije, brige za druge. }\end{array}$ & $\begin{array}{l}\text { Hrvatsko } \\
\text { društvo } \\
\text { književnika } \\
\text { za djecu i } \\
\text { mlade }\end{array}$ \\
\hline $\begin{array}{l}\text { Fantastic } \\
\text { Beasts: The } \\
\text { Crimes of } \\
\text { Grindelwald - } \\
\text { The Original } \\
\text { Screenplay - J. } \\
\text { K. Rowling } \\
\end{array}$ & $\begin{array}{l}\text { Film--Montaža } \\
\text { Filmska pro- } \\
\text { dukcija--SAD } \\
\text { Filmska umjet- } \\
\text { nost -- Anima- } \\
\text { cija }\end{array}$ & 2018. & Scenarij & $\begin{array}{l}\text { Borba čarobnjaka i } \\
\text { magičnih bića; ele- } \\
\text { menti ljubavi, prija- } \\
\text { teljstva. }\end{array}$ & $\begin{array}{l}\text { Hachette } \\
\text { UK }\end{array}$ \\
\hline
\end{tabular}




\begin{tabular}{|c|c|c|c|c|c|}
\hline $\begin{array}{l}\text { Divlja lje- } \\
\text { potica - } 1 . \\
\text { dio trilogije } \\
\text { „Knjiga o Pra- } \\
\text { hu“ - Philip } \\
\text { Pullman } \\
\end{array}$ & \begin{tabular}{|l} 
Fantastični ro- \\
man -- Engleska \\
književnost \\
Bajkoviti roman \\
-- Engleska \\
književnost \\
\end{tabular} & 2018. & Roman & $\begin{array}{l}\text { Svakodnevni život } \\
\text { demona, ljubav. }\end{array}$ & $\begin{array}{l}\text { Lumen } \\
\text { izdavaštvo }\end{array}$ \\
\hline \begin{tabular}{|l} 
Čudesna \\
zemlja Oz-- \\
Lyman Frank \\
Baum \\
\end{tabular} & $\begin{array}{l}\text { Bajkoviti roman } \\
\text {-- Američka } \\
\text { književnost }\end{array}$ & 2018. & Roman & $\begin{array}{l}\text { Pobuna protiv aktu- } \\
\text { alne vlasti u čude- } \\
\text { snoj zemlji. }\end{array}$ & VF Libris \\
\hline $\begin{array}{l}\text { Zapetljani } \\
\text { svijet - A. G. } \\
\text { Howard }\end{array}$ & $\begin{array}{l}\text { Fantastični ro- } \\
\text { man -- Američ- } \\
\text { ka književnost } \\
\text { Ljubavni roman } \\
\text {-- Američka } \\
\text { književnost }\end{array}$ & 2018. & Roman & $\begin{array}{l}\text { Gotičarska chick-lit } \\
\text { knjiga; tema ljubavi } \\
\text { i odabir partnera u } \\
\text { čudesnoj zemlji, bor- } \\
\text { ba s drugim bićima. }\end{array}$ & $\begin{array}{l}\text { Lumen } \\
\text { izdavaštvo }\end{array}$ \\
\hline $\begin{array}{l}\text { A Song of Ice } \\
\text { and Fire - Fire } \\
\text { and Blood: } \\
300 \text { Years Be- } \\
\text { fore A Game } \\
\text { of Thrones } \\
\text { (A Targaryen } \\
\text { History) - } \\
\text { George R. R. } \\
\text { Martin } \\
\end{array}$ & $\begin{array}{l}\text { Fantastična pro- } \\
\text { za -- Američka } \\
\text { književnost }\end{array}$ & 2018. & Roman & $\begin{array}{l}\text { Teme čarobnog i } \\
\text { realističnog, politike } \\
\text { i društva, moralne } \\
\text { dvojbe likova, nasilje } \\
\text { i smrt. }\end{array}$ & $\begin{array}{l}\text { Harper } \\
\text { Collins }\end{array}$ \\
\hline $\begin{array}{l}\text { Pjesma leda i } \\
\text { vatre 4, Gozba } \\
\text { vrana - Geor- } \\
\text { ge R.R. Martin } \\
\end{array}$ & $\begin{array}{l}\text { Povijesni prikaz } \\
\text { Fantastična pro- } \\
\text { za -- Američka } \\
\text { književnost } \\
\end{array}$ & 2018. & Roman & $\begin{array}{l}\text { Spletke i prijevare; } \\
\text { borba za prijestolje. }\end{array}$ & $\begin{array}{l}\text { Lumen } \\
\text { izdavaštvo }\end{array}$ \\
\hline $\begin{array}{l}\text { Polarna svje- } \\
\text { tlost - I. dio } \\
\text { serijala Nje- } \\
\text { gova mračna } \\
\text { građa - Philip } \\
\text { Pullman }\end{array}$ & $\begin{array}{l}\text { Fantastički ro- } \\
\text { man -- } \\
\text { Socijalni roman } \\
\text {-- Američka } \\
\text { književnost } \\
\text { Povijesni roman } \\
\text {-- Američka } \\
\text { književnost } \\
\end{array}$ & 2018. & Roman & $\begin{array}{l}\text { Paralelni svijet, kri- } \\
\text { tiziranje religije i } \\
\text { Crkve. }\end{array}$ & $\begin{array}{l}\text { Lumen } \\
\text { izdavaštvo }\end{array}$ \\
\hline \begin{tabular}{|l|} 
Čudesni nož \\
- II. dio seri- \\
jala Njegova \\
mračna građa \\
- Philip Pull- \\
man \\
\end{tabular} & $\begin{array}{l}\text { Fantastični ro- } \\
\text { man -- Engleska } \\
\text { književnost } \\
\text { Bajkoviti roman } \\
\text {-- Engleska } \\
\text { književnost } \\
\end{array}$ & 2018. & Roman & $\begin{array}{l}\text { Borba zlih sila i de- } \\
\text { mona, raj nasuprot } \\
\text { paklu, život nasuprot } \\
\text { smrti. }\end{array}$ & $\begin{array}{l}\text { Lumen } \\
\text { izdavaštvo }\end{array}$ \\
\hline
\end{tabular}




\begin{tabular}{|c|c|c|c|c|c|}
\hline \begin{tabular}{|l|} 
Jantarni dale- \\
kozor - III. dio \\
serijala Nje- \\
gova mračna \\
građa - Philip \\
Pullman \\
\end{tabular} & \begin{tabular}{|l|} 
Fantastični ro- \\
man -- Engleska \\
književnost \\
Bajkoviti roman \\
-- Engleska \\
književnost \\
\end{tabular} & 2018. & Roman & $\begin{array}{l}\text { Oslobođenje ljud- } \\
\text { skog roda od jarma } \\
\text { sudbine. }\end{array}$ & \begin{tabular}{|l|} 
Lumen \\
izdavaštvo
\end{tabular} \\
\hline $\begin{array}{l}\text { Mrak na ob- } \\
\text { zoru - Sabaa } \\
\text { Tahir }\end{array}$ & \begin{tabular}{|l|} 
Fantastični ro- \\
man -- Američ- \\
ka književnost
\end{tabular} & 2018. & Roman & Borbe mračnih sila. & \begin{tabular}{|l|} 
Lumen \\
izdavaštvo
\end{tabular} \\
\hline $\begin{array}{l}\text { Priče o čudno- } \\
\text { vatima - Ran- } \\
\text { som Riggs }\end{array}$ & $\begin{array}{l}\text { Fantastične pri- } \\
\text { če -- Američka } \\
\text { književnost } \\
\text { Psihološke priče } \\
\text {-- Američka } \\
\text { književnost }\end{array}$ & 2018. & Roman & $\begin{array}{l}\text { Zamišljeni svijet, } \\
\text { jezive priče s pleme- } \\
\text { nitim i ohrabrujućim } \\
\text { poukama. }\end{array}$ & $\begin{array}{l}\text { Lumen } \\
\text { izdavaštvo }\end{array}$ \\
\hline $\begin{array}{l}\text { Nasljednica } \\
\text { vatre - Sarah J. } \\
\text { Maas }\end{array}$ & $\begin{array}{l}\text { Fantastični ro- } \\
\text { man -- Američ- } \\
\text { ka književnost }\end{array}$ & 2018. & Roman & $\begin{array}{l}\text { Demonski svijet, ali } \\
\text { i prijateljstvo, osveta, } \\
\text { suočavanje s vlasti- } \\
\text { tim podrijetlom. }\end{array}$ & $\begin{array}{l}\text { Fokus ko- } \\
\text { munikacije } \\
\text { d.o.o. }\end{array}$ \\
\hline $\begin{array}{l}\text { Oksa Pollock } \\
\text { - Posljednja } \\
\text { zvijezda, } 6 . \\
\text { Knjiga - Anne } \\
\text { Plichota, Cen- } \\
\text { drine Wolf } \\
\end{array}$ & $\begin{array}{l}\text { Fantastični ro- } \\
\text { man -- Francu- } \\
\text { ska književnost }\end{array}$ & 2018. & Roman & $\begin{array}{l}\text { Borba protiv zla, } \\
\text { spašavanje svijeta, } \\
\text { magija, sudbina. }\end{array}$ & \begin{tabular}{|l|} 
Lumen \\
izdavaštvo
\end{tabular} \\
\hline $\begin{array}{l}\text { Deset tisuća } \\
\text { života - Mic- } \\
\text { hael Poore }\end{array}$ & \begin{tabular}{|l|} 
Fantastični ro- \\
man -- Američ- \\
ka književnost \\
Ljubavni roman \\
-- Američka \\
književnost \\
\end{tabular} & 2018. & Roman & $\begin{array}{l}\text { Filozofska pitanja } \\
\text { o ljudskoj prirodi i } \\
\text { nasumičnosti života, } \\
\text { a u skladu s budistič- } \\
\text { kim učenjem. }\end{array}$ & $\begin{array}{l}\text { Lumen } \\
\text { izdavaštvo }\end{array}$ \\
\hline $\begin{array}{l}\text { Sjena bronča- } \\
\text { nog štakora } \\
\text { - Mladen Ko- } \\
\text { pjar }\end{array}$ & \begin{tabular}{|l|} 
Fantastični \\
roman -- Hrvat- \\
ska književnost
\end{tabular} & 2018. & Roman & $\begin{array}{l}\text { Ljubav, roditeljsko } \\
\text { nerazumijevanje, } \\
\text { socijalni problemi, } \\
\text { sfera okultnog i mi- } \\
\text { stičnog. }\end{array}$ & $\begin{array}{l}\text { Naklada } \\
\text { Ljevak }\end{array}$ \\
\hline $\begin{array}{l}\text { Igrač broj } \\
\text { jedan - Ernest } \\
\text { Cline }\end{array}$ & $\begin{array}{l}\text { Fantastični } \\
\text { roman --Znan- } \\
\text { stveno fanta- } \\
\text { stični roman } \\
\text {-- Američka } \\
\text { književnost }\end{array}$ & 2018. & Roman & $\begin{array}{l}\text { Radnja u budućno- } \\
\text { sti, 2045. godine. } \\
\text { Priča o tinejdžeru } \\
\text { koji se osjeća živim } \\
\text { samo kada boravi u } \\
\text { virtualnom svijetu } \\
\text { (utopijskom). }\end{array}$ & $\begin{array}{l}\text { Vorto Pala- } \\
\text { bra }\end{array}$ \\
\hline
\end{tabular}




\begin{tabular}{|c|c|c|c|c|c|}
\hline $\begin{array}{l}\text { Odd i mrazni } \\
\text { divovi - Neil } \\
\text { Gaiman }\end{array}$ & $\begin{array}{l}\text { Mitološki ro- } \\
\text { man -- Engleska } \\
\text { književnost }\end{array}$ & 2018. & $\begin{array}{l}\text { Slikov- } \\
\text { nica }\end{array}$ & $\begin{array}{l}\text { Likovi Nordijske } \\
\text { mitologije i dječak } \\
\text { koji spašavaju svijet } \\
\text { od mraznih divova i } \\
\text { vječne zime. }\end{array}$ & Mitopeja \\
\hline $\begin{array}{l}\text { Nordijska mi- } \\
\text { tologija - Neil } \\
\text { Gaiman }\end{array}$ & $\begin{array}{l}\text { Mitološke } \\
\text { pripovijetke -- } \\
\text { Engleska knji- } \\
\text { ževnost } \\
\text { Nordijska mito- } \\
\text { logija }\end{array}$ & 2018. & Roman & $\begin{array}{l}\text { Život nordijskih } \\
\text { bogova s elementima } \\
\text { prijateljstva i kom- } \\
\text { pliciranih obiteljskih } \\
\text { odnosa. }\end{array}$ & Mitopeja \\
\hline $\begin{array}{l}\text { Medvjed i } \\
\text { slavuj - Kathe- } \\
\text { rine Arden }\end{array}$ & $\begin{array}{l}\text { Mitološki ro- } \\
\text { man -- Američ- } \\
\text { ka književnost }\end{array}$ & 2018. & Roman & $\begin{array}{l}\text { Radnja smještena u } \\
\text { povijesne ruske ze- } \\
\text { mlje s kraja } 14 \text {. sto- } \\
\text { ljeća baš kao i svijet } \\
\text { ruske mitologije. }\end{array}$ & Mitopeja \\
\hline $\begin{array}{l}\text { Djevojka u } \\
\text { tornju - Kat- } \\
\text { herine Arden }\end{array}$ & $\begin{array}{l}\text { Mitološki ro- } \\
\text { man -- Američ- } \\
\text { ka književnost }\end{array}$ & 2018. & Roman & $\begin{array}{l}\text { Nastavak knjige } \\
\text { Medvjed i Slavuj sa } \\
\text { sličnim elementima } \\
\text { ruske mitologije; po- } \\
\text { litika toga vremena. }\end{array}$ & Mitopeja \\
\hline $\begin{array}{l}\text { Tajna zmaj- } \\
\text { skog mosta - } \\
\text { Anđa Marić }\end{array}$ & $\begin{array}{l}\text { Fantastični } \\
\text { roman -- Hrvat- } \\
\text { ska književnost } \\
\text { Mitološki ro- } \\
\text { man -- Hrvat- } \\
\text { ska književnost }\end{array}$ & 2018. & Roman & $\begin{array}{l}\text { Legenda o mostu u } \\
\text { Ljubljani s elemen- } \\
\text { tima fantastike kroz } \\
\text { priču o nesretnom } \\
\text { zmaju. }\end{array}$ & Semafora \\
\hline $\begin{array}{l}\text { Zefir - Sonja } \\
\text { Smolec }\end{array}$ & $\begin{array}{l}\text { Fantastični } \\
\text { roman -- Hrvat- } \\
\text { ska književnost }\end{array}$ & 2019. & Roman & $\begin{array}{l}\text { Putovanje u izmišlje- } \\
\text { ni svijet. }\end{array}$ & $\begin{array}{l}\text { Naklada } \\
\text { Bošković }\end{array}$ \\
\hline $\begin{array}{l}\text { Sumrak na Vi- } \\
\text { linskim polja- } \\
\text { nama - Nada } \\
\text { Mihaljević }\end{array}$ & $\begin{array}{l}\text { Bajkoviti roman } \\
\text {-- Hrvatska } \\
\text { književnost }\end{array}$ & 2019. & Roman & $\begin{array}{l}\text { Borbe vilinskog i } \\
\text { ljudskog svijeta. }\end{array}$ & $\begin{array}{l}\text { Umjetnička } \\
\text { organizacija } \\
\text { Knjigohvat }\end{array}$ \\
\hline $\begin{array}{l}\text { Kći dima i } \\
\text { kosti - Laini } \\
\text { Taylor }\end{array}$ & $\begin{array}{l}\text { Fantastični ro- } \\
\text { man -- Američ- } \\
\text { ka književnost }\end{array}$ & 2019. & Roman & $\begin{array}{l}\text { Ljubav, nadnaravni } \\
\text { rat. }\end{array}$ & $\begin{array}{l}\text { Vorto Pala- } \\
\text { bra }\end{array}$ \\
\hline \begin{tabular}{l|} 
Šest vrana - \\
Leigh Bardugo
\end{tabular} & $\begin{array}{l}\text { Fantastični ro- } \\
\text { man -- Američ- } \\
\text { ka književnost }\end{array}$ & 2019. & Roman & $\begin{array}{l}\text { Ranjiva djeca na } \\
\text { pragu odraslosti, } \\
\text { traženje identiteta, } \\
\text { magija, prijateljska } \\
\text { ljubav. }\end{array}$ & Znanje \\
\hline
\end{tabular}


Ivana MARTINOVIĆ, Ivona GRGIĆ, Elizabeta KOTROMANOVIĆ: UŽITAK U ČITANJU: TEME U LITERATURI...

\begin{tabular}{|l|l|l|l|l|l|}
\hline $\begin{array}{l}\text { Društvo ča- } \\
\text { robnih jedno- } \\
\text { roga - Selwyn } \\
\text { E. Phipps }\end{array}$ & $\begin{array}{l}\text { Jednorozi -- } \\
\text { Prikaz } \\
\text { Bajkovite priče } \\
\text {-- Engleska } \\
\text { književnost }\end{array}$ & 2019. & $\begin{array}{l}\text { Priruč- } \\
\text { nik }\end{array}$ & $\begin{array}{l}\text { Mitska bića, čudesan } \\
\text { svijet jednoroga. }\end{array}$ & $\begin{array}{l}\text { Naklada } \\
\text { Ljevak }\end{array}$ \\
\hline $\begin{array}{l}\text { Nikadgrad } \\
\text { - Kušnje } \\
\begin{array}{l}\text { Morrigan } \\
\text { Crow - Jessica } \\
\text { Townsend }\end{array}\end{array}$ & $\begin{array}{l}\text { Fantastični ro- } \\
\text { man -- Austral- } \\
\text { ska književnost }\end{array}$ & 2019. & Roman & $\begin{array}{l}\text { Čudesno i magično } \\
\text { mjesto, ukleta dje- } \\
\text { vojčica. }\end{array}$ & Znanje \\
\hline $\begin{array}{l}\text { Zima za vješti- } \\
\text { cu- Katherine } \\
\text { Arden }\end{array}$ & $\begin{array}{l}\text { Mitološki ro- } \\
\text { man -- Američ- } \\
\text { ka književnost }\end{array}$ & 2019. & Roman & $\begin{array}{l}\text { Spoj zemaljskog i } \\
\text { nadzemaljskog - ča- } \\
\text { robni svijet demona i } \\
\text { čortova stare pogan- } \\
\text { ske religije. }\end{array}$ & Mitopeja \\
\hline
\end{tabular}

\section{B) Realistična djela}

Realistična djela bave se temama nešto teže naravi. Naime, $u$ djelima realističnog karaktera likovi su i jaki i ranjivi, nose se sa stvarnim društvenim i emocionalnim problemima, pred njima su ekonomske brige i životne odluke (usp. Trupe 2006: VII). Djela suvremene književnosti za mlade donose teme poput zlostavljanja, prihvaćanja razlika, prilagodbe, ovisnosti, životinja i okoliša, ljepote, zločina, samoubojstva, ljubavi i ljubavnih problema, bolesti, obitelji, prijateljstva, povijesti, izmišljenih mjesta i budućnosti, odrastanja, siromaštva, seksualnog identiteta i sl. Dakle, gotovo svaka knjiga, neovisno o žanru kojemu pripada, ima elemente realističnih djela, posebice kada su u pitanju djela za mlade gdje se iza svake misli krije pouka. Ipak, nije svaka od navedenih tema zastupljena u knjigama izdvojenim ovim istraživanjem, ali svaka od tih knjiga donosi temu koja predstavlja stvarnu životnu situaciju nekih mladih pojedinaca.

\section{Obitelj (obiteljska djela)}

Obitelji imaju vrlo veliku ulogu u oblikovanju pojedinca, a dolaze u širokom rasponu. Neki ljudi žive u kućanstvu zajedno s nekoliko generacija obitelji, a drugi u jednoroditeljskim; neki su jedinci, neki žive s braćom i sestrama. Obiteljska povijest i tradicije oblikuju svakodnevni život pojedinca, dok drugi žive u relativno izoliranim nuklearnim obiteljima. Obitelji su oblikovane kulturnim očekivanjima, a ta očekivanja oblikuju mogućnosti i za pojedince. Rodne uloge, socioekonomski status, obrazovne mogućnosti - sve se to odražava u obiteljima 
u kojima pojedinci rastu do odrasle dobi. Različiti obiteljski obrasci oblikuju živote mladih protagonista u navedenim djelima (usp. Trupe 2006: 83).

\section{Problemi pojedinca i društva (psihološka djela)}

Gotovo svako od navedenih realističnih djela bavi se, na neki način, aktualnim (sveprisutnim) problemima čovjeka kao pojedinca, ali i društva u cjelini. Problem s obitelji, prijateljima ili problemi u ljubavi česta su tema takvih djela. Međutim, neki problemi koji se u djelima javljaju djelomično su ili u potpunosti ograničeni na sadašnje stoljeće. Pitanje seksualnosti i seksualnog identiteta je ono koje se postavljalo uvijek, no prihvaćanje razlika u tom aspektu života mladih i odmicanje od stava da je seksualnost tabu-tema djela takvog karaktera učinilo je nešto popularnijim u 21. stoljeću. Jedna je od glavnih karakteristika adolescencije seksualno sazrijevanje, a učenje upravljanja seksualnom privlačnošću - znati kada djelovati, s kime i koliko daleko - dominantna je briga u razdoblju mlade odrasle dobi. Mladi se moraju nositi s pritiscima vlastitih tijela, s vršnjačkim pritiskom, ponekad sukobljenim zahtjevima ljubavi, očekivanjima obitelji itd. Posebice je važno osvrnuti se na prihvaćanje razlika u kontekstu različitih seksualnih identiteta. Stoga, knjige koje opisuju živote homoseksualaca, biseksualaca i nesigurnosti kada je u pitanju vlastiti identitet, važna su štiva koja mladima mogu pomoći razumjeti vlastite i tuđe nagone (usp. Trupe 2006: 203). Još jedna tema sve više obuhvaćena u knjigama za mlade jest internet; konkretnije, društveni mediji. Facebook je prošao kroz gotovo cijeli svijet. Kao i drugi društveni mediji, on omogućuje svima, pa tako i mladima, komunikaciju s ljudima neovisno o njihovoj lokaciji ili dobu dana. Te platforme omogućuju također praćenje osoba koje mladi smatraju uzorima i širenje virtualnog društvenog kruga. U djelima je prisutna i tema ovisnosti. Neka djela bave se odgovorima na pitanje što učiniti kada su mladi sami sebi najgori neprijatelji. Suicidalni osjećaji često se ne prijavljuju zbog stigmatizacije emocionalnih problema od strane vršnjaka ili nedostatka pažnje odraslih u njihovim životima. U nekim slučajevima, odrasli u obitelji ne doživljavaju promjene raspoloženja onoliko ozbiljno koliko bi možda trebali, vjerujući da su normalne u adolescenciji. Nadalje, mnogi tinejdžeri prolaze kroz iznimno stresne situacije i traume koje potiču depresiju. Stoga, nije neuobičajeno da je emocionalni poremećaj glavna tema mnogih romana za mlade. $U$ nekim od tih romana mladi se suočavaju s depresijom ili drugim emocionalnim problemima te pokušavaju pronaći put do emocionalne ravnoteže ili započinju svoje putovanje natrag, s podrškom bliskih prijatelja ili mentora koji prepoznaju prirodu problema (usp. Trupe 2006: 75). 


\section{Prijateljstvo (društvena djela)}

U adolescenciji vršnjaci zamjenjuju članove obitelji te postaju primarne osobe od povjerenja i poticaj u promjeni ponašanja. Ponekad se čini da će se tada formirani odnosi održati zauvijek. To je također razdoblje neizmjernog rasta i promjena, čimbenika koji dovode u pitanje ta prijateljstva. Razni vanjski utjecaji i unutarnje promjene mogu utjecati na daljnji razvoj ili kraj prijateljstva (usp. Trupe 2006: 91). Ipak, prijateljstvo je važan element mnogih romana koji su izdani u Hrvatskoj, a barem u sporednom kontekstu spominje se u svakom djelu, neovisno o žanru. Navedeni naslovi donose temu prijateljstva kao glavno obilježje djela kao što je prikazano u Tablici 2.

Tablica 2. Realistična djela

\begin{tabular}{|l|l|l|l|l|l|}
\hline $\begin{array}{l}\text { Naslov knjige } \\
\text { i autor }\end{array}$ & $\begin{array}{l}\text { Predmetna } \\
\text { odrednica } \\
\text { knjižnice }\end{array}$ & $\begin{array}{l}\text { Godina } \\
\text { izdanja }\end{array}$ & $\begin{array}{l}\text { Vrsta } \\
\text { djela }\end{array}$ & $\begin{array}{l}\text { Tematska } \\
\text { obilježja djela }\end{array}$ & Nakladnik \\
\hline $\begin{array}{l}\text { Milijunaši - } \\
\text { Maja Brajko- } \\
\text { Livaković }\end{array}$ & $\begin{array}{l}\text { Obiteljski roman } \\
\text {-- Hrvatska knji- } \\
\text { ževnost } \\
\text { Društveni roman } \\
-- \text { Hrvatska knji- } \\
\text { ževnost } \\
\text { Suvremeni roman } \\
\text {-- Hrvatska knji- } \\
\text { ževnost }\end{array}$ & 2016. & Roman & $\begin{array}{l}\text { Težnja za boga- } \\
\text { ćenjem, suoča- } \\
\text { vanje mladih s } \\
\text { roditeljima koji } \\
\text { su se ogriješili o } \\
\text { zakon, očuvanje } \\
\text { obitelji. }\end{array}$ & ALFA d.d. \\
\hline $\begin{array}{l}\text { Obožavatelji- } \\
\text { ca- Rainbow } \\
\text { Rowell }\end{array}$ & $\begin{array}{l}\text { Psihološki roman } \\
-- \text { Američka knji- } \\
\text { ževnost }\end{array}$ & 2016. & Roman & $\begin{array}{l}\text { Fanfikcija, } \\
\text { tema odrastanja } \\
\text { i promjena vla- } \\
\text { stitog života. }\end{array}$ & Znanje \\
\hline $\begin{array}{l}\text { Pošalji mi } \\
\text { poruku! - Sa- } \\
\text { nja Pilić }\end{array}$ & $\begin{array}{l}\text { Suvremene pripo- } \\
\text { vijetke -- Hrvatska } \\
\text { književnost } \\
\text { Psihološke pripo- } \\
\text { vijetke -- Hrvatska } \\
\text { književnost }\end{array}$ & 2016. & Roman & $\begin{array}{l}\text { Netipična dje- } \\
\text { vojka i ljubavna } \\
\text { veza, komuni- } \\
\text { kacija Youtube- } \\
\text { om. }\end{array}$ & $\begin{array}{l}\text { Mozaik knji- } \\
\text { ga }\end{array}$ \\
\hline
\end{tabular}

Fanfikcija - pisana forma koju proizvode obožavatelji, a koristi se već prethodno osmišljenim likovima i/ili prostorima posuđenim iz drugih priča. 


\begin{tabular}{|c|c|c|c|c|c|}
\hline $\begin{array}{l}\text { Bojno polje } \\
\text { uma - za } \\
\text { tinejdžere - } \\
\text { Todd Hafer, } \\
\text { Joyce Meyer }\end{array}$ & $\begin{array}{l}\text { Mladež -- Psiholo- } \\
\text { gija sazrijevanja -- } \\
\text { Kršćansko gledište } \\
\text {-- Savjetnik } \\
\text { Mladež -- Psiholo- } \\
\text { gija sazrijevanja } \\
\end{array}$ & 2016. & Priručnik & $\begin{array}{l}\text { Mudri savjeti za } \\
\text { tinejdžere. }\end{array}$ & $\begin{array}{l}\text { Logos } \mathrm{Da}- \\
\text { ruvar }\end{array}$ \\
\hline $\begin{array}{l}\text { Sasvim sam } \\
\text { popubertetio } \\
\text { - Sanja Pilić }\end{array}$ & $\begin{array}{l}\text { Obiteljski roman } \\
\text {-- Hrvatska knji- } \\
\text { ževnost }\end{array}$ & 2016. & Roman & $\begin{array}{l}\text { Pubertet, odno- } \\
\text { si s djevojkama, } \\
\text { školski, obitelj- } \\
\text { ski i ljubavni } \\
\text { problemi. }\end{array}$ & $\begin{array}{l}\text { Mozaik knji- } \\
\text { ga }\end{array}$ \\
\hline $\begin{array}{l}\text { Will Grayson, } \\
\text { Will Grayson } \\
\text { - John Green, } \\
\text { David Levi- } \\
\text { than }\end{array}$ & $\begin{array}{l}\text { Psihološki roman } \\
\text {-- Američka knji- } \\
\text { ževnost } \\
\text { Humoristički ro- } \\
\text { man -- Američka } \\
\text { književnost } \\
\end{array}$ & 2017. & Roman & $\begin{array}{l}\text { Tema homo- } \\
\text { seksualnosti, } \\
\text { prijateljstva i } \\
\text { glazbe. }\end{array}$ & $\begin{array}{l}\text { Fokus komu- } \\
\text { nikacije }\end{array}$ \\
\hline $\begin{array}{l}\text { Borba za ži- } \\
\text { vot - Marina } \\
\text { Kljajo-Radić }\end{array}$ & $\begin{array}{l}\text { Obiteljski roman } \\
\text {-- Hrvatska knji- } \\
\text { ževnost } \\
\text { Obrazovni roman } \\
\text {-- Hrvatska knji- } \\
\text { ževnost } \\
\end{array}$ & 2017. & Roman & \begin{tabular}{|l|} 
Rizična trud- \\
noća, Downov \\
sindrom, borba \\
za život od \\
strane djeteta i \\
majke. \\
\end{tabular} & ALFA d.d. \\
\hline $\begin{array}{l}\text { Stavit ću te } \\
\text { na Facebook! } \\
\text { - Katarina } \\
\text { Solomun }\end{array}$ & $\begin{array}{l}\text { Psihološki roman } \\
\text {-- Hrvatska knji- } \\
\text { ževnost } \\
\text { Suvremeni roman } \\
\text {-- Hrvatska knji- } \\
\text { ževnost } \\
\end{array}$ & 2017. & Roman & $\begin{array}{l}\text { Vršnjačko na- } \\
\text { silje na Facebo- } \\
\text { oku. }\end{array}$ & Studio Tim \\
\hline $\begin{array}{l}\text { Svaka cura } \\
\text { ima svoju pri- } \\
\text { ču } 3 \text { - Eleanor } \\
\text { Watkins }\end{array}$ & $\begin{array}{l}\text { Društvene priče } \\
\text {-- Engleska knji- } \\
\text { ževnost } \\
\text { Religiozne priče } \\
\text {-- Engleska knji- } \\
\text { ževnost }\end{array}$ & 2017. & Roman & $\begin{array}{l}\text { Financijska } \\
\text { kriza u obitelji, } \\
\text { pravo značenje } \\
\text { Božića, spozna- } \\
\text { ja vrijednosti } \\
\text { obitelji, prija- } \\
\text { teljstva i vjere. }\end{array}$ & Verbum \\
\hline $\begin{array}{l}\text { Nespomenu- } \\
\text { ta-Francine } \\
\text { Rivers }\end{array}$ & $\begin{array}{l}\text { Društveni roman } \\
\text {-- Američka knji- } \\
\text { ževnost } \\
\text { Religiozni roman } \\
\text {-- Američka knji- } \\
\text { ževnost }\end{array}$ & 2017. & Roman & $\begin{array}{l}\text { Biblijska pripo- } \\
\text { vijest o ljubavi, } \\
\text { priča o preljubu } \\
\text { i potrazi za } \\
\text { opraštanjem. }\end{array}$ & Verbum \\
\hline
\end{tabular}




\begin{tabular}{|c|c|c|c|c|c|}
\hline $\begin{array}{l}\text { U vodu } \\
\text { - Paula } \\
\text { Hawkins }\end{array}$ & $\begin{array}{l}\text { Psihološki triler } \\
\text {-- Engleska knji- } \\
\text { ževnost } \\
\text { Kriminalistički } \\
\text { roman -- Engleska } \\
\text { književnost }\end{array}$ & 2017. & Roman & $\begin{array}{l}\text { Neuhvatljivost } \\
\text { istine i obitelji } \\
\text { koja se raspada } \\
\text { zbog tajni - mi- } \\
\text { steriozne smrti } \\
\text { žena i gubitak } \\
\text { voljenih. }\end{array}$ & $\begin{array}{l}\text { Mozaik knji- } \\
\text { ga }\end{array}$ \\
\hline $\begin{array}{l}\text { Par iz susjed- } \\
\text { stva - Shari } \\
\text { Lapena }\end{array}$ & $\begin{array}{l}\text { Psihološki roman } \\
\text {-- Kanadska knji- } \\
\text { ževnost } \\
\text { Triler -- Kanadska } \\
\text { književnost }\end{array}$ & 2017. & Roman & $\begin{array}{l}\text { Podloga iza na- } \\
\text { oko savršenog } \\
\text { života u elitnom } \\
\text { predgrađu. }\end{array}$ & $\begin{array}{l}\text { Mozaik knji- } \\
\text { ga }\end{array}$ \\
\hline $\begin{array}{l}\text { Ljeto na } \\
\text { jezeru Čiču } \\
\text { - Jasminka } \\
\text { Tihi-Stepanić }\end{array}$ & $\begin{array}{l}\text { Obiteljski roman } \\
\text {-- Hrvatska knji- } \\
\text { ževnost } \\
\text { Društveni roman } \\
\text {-- Hrvatska knji- } \\
\text { ževnost }\end{array}$ & 2018. & Roman & $\begin{array}{l}\text { Socijalni obi- } \\
\text { teljski problemi, } \\
\text { ljubavni proble- } \\
\text { mi tinejdžerice. }\end{array}$ & $\begin{array}{l}\text { Naklada } \\
\text { Ljevak }\end{array}$ \\
\hline $\begin{array}{l}\text { Druga obala } \\
\text { - Dugo puto- } \\
\text { vanje u bijelo } \\
\text { - Mirjana } \\
\text { Buljan }\end{array}$ & $\begin{array}{l}\text { Psihološki roman } \\
\text {-- Hrvatska knji- } \\
\text { ževnost }\end{array}$ & 2018. & Roman & $\begin{array}{l}\text { Problemi od- } \\
\text { goja, razvod } \\
\text { - posljedice za } \\
\text { dijete. }\end{array}$ & $\begin{array}{l}\text { Naklada } \\
\text { Ljevak }\end{array}$ \\
\hline $\begin{array}{l}\text { Moje ljeto s } \\
\text { Picassom - } \\
\text { Vjekoslava } \\
\text { Huljić }\end{array}$ & $\begin{array}{l}\text { Obiteljski roman } \\
\text {-- Hrvatska knji- } \\
\text { ževnost }\end{array}$ & 2018. & Roman & $\begin{array}{l}\text { Tema obitelj- } \\
\text { skog problema } \\
\text { tinejdžerice } \\
\text { koja ne voli } \\
\text { svog polubrata i } \\
\text { koja doživljava } \\
\text { otmicu. }\end{array}$ & $\begin{array}{l}\text { Mozaik knji- } \\
\text { ga }\end{array}$ \\
\hline $\begin{array}{l}\text { S ljubavlju, Si- } \\
\text { mon - Becky } \\
\text { Albertalli }\end{array}$ & $\begin{array}{l}\text { Suvremeni roman } \\
\text {-- Američka knji- } \\
\text { ževnost } \\
\text { Psihološki roman } \\
\text {-- Američka knji- } \\
\text { ževnost }\end{array}$ & 2018. & Roman & $\begin{array}{l}\text { Odrastanje u } \\
\text { 21. st.; homo- } \\
\text { seksualnost. }\end{array}$ & $\begin{array}{l}\text { Vorto Pala- } \\
\text { bra }\end{array}$ \\
\hline $\begin{array}{l}\text { Nikad kraja } \\
\text { kornjačama - } \\
\text { John Green }\end{array}$ & $\begin{array}{l}\text { Psihološki roman } \\
\text {-- Američka knji- } \\
\text { ževnost } \\
\text { Društveni roman } \\
\text {-- Američka knji- } \\
\text { ževnost }\end{array}$ & 2018. & Roman & $\begin{array}{l}\text { Napadaji pani- } \\
\text { ke i opsesivne } \\
\text { misli. }\end{array}$ & $\begin{array}{l}\text { Fokus komu- } \\
\text { nikacije }\end{array}$ \\
\hline
\end{tabular}




\begin{tabular}{|c|c|c|c|c|c|}
\hline $\begin{array}{l}\text { Beckomberga } \\
\text { - Oda mojoj } \\
\text { obitelji - Sara } \\
\text { Stridsberg }\end{array}$ & $\begin{array}{l}\text { Psihološki roman } \\
\text {-- Švedska književ- } \\
\text { nost } \\
\text { Obiteljski roman } \\
\text {-- Švedska književ- } \\
\text { nost } \\
\text { Suvremeni roman } \\
\text {-- Švedska književ- } \\
\text { nost }\end{array}$ & 2018. & Roman & $\begin{array}{l}\text { Život u psihija- } \\
\text { trijskoj bolnici } \\
\text { nakon pokušaja } \\
\text { samoubojstva. }\end{array}$ & $\begin{array}{l}\text { Naklada } \\
\text { Ljevak }\end{array}$ \\
\hline $\begin{array}{l}13 \text { minuta - } \\
\text { Sarah Pinbo- } \\
\text { rough }\end{array}$ & $\begin{array}{l}\text { Psihološki roman } \\
\text {-- Engleska knji- } \\
\text { ževnost }\end{array}$ & 2018. & Roman & $\begin{array}{l}\text { Prijateljstvo i } \\
\text { izdaja, rješava- } \\
\text { nje misterija uz } \\
\text { pomoć prijate- } \\
\text { lja, suočavanje } \\
\text { sa strahovima, } \\
\text { manipulacija i } \\
\text { moć istine. }\end{array}$ & $\begin{array}{l}\text { Naklada } \\
\text { Ljevak }\end{array}$ \\
\hline $\begin{array}{l}\text { Pravila magije } \\
\text { - Alice Hoff- } \\
\text { man }\end{array}$ & $\begin{array}{l}\text { Obiteljski roman } \\
\text {-- Američka knji- } \\
\text { ževnost } \\
\text { Ljubavni roman } \\
\text {-- Američka knji- } \\
\text { ževnost }\end{array}$ & 2018. & Roman & $\begin{array}{l}\text { Raskošna, } \\
\text { uzbudljiva i } \\
\text { potresna priča } \\
\text { o obitelji i snazi } \\
\text { ljubavi. Kletva } \\
\text { stara više stoti- } \\
\text { na godina utje- } \\
\text { če na obiteljski } \\
\text { i ljubavni život } \\
\text { obitelji Owens- }\end{array}$ & $\begin{array}{l}\text { Profil knjiga } \\
\text { d.o.o. }\end{array}$ \\
\hline $\begin{array}{l}\text { Tri hrabrice } \\
\text { - Kate DiCa- } \\
\text { millo }\end{array}$ & $\begin{array}{l}\text { Obiteljski roman } \\
\text {-- Američka knji- } \\
\text { ževnost } \\
\text { Psihološki roman } \\
\text {-- Američka knji- } \\
\text { ževnost }\end{array}$ & 2018. & Roman & $\begin{array}{l}\text { Priča o ljubavi i } \\
\text { gubitku te pu- } \\
\text { stolovini glavne } \\
\text { junakinje; pro- } \\
\text { blemi s ocem i } \\
\text { želja za dokazi- } \\
\text { vanjem. }\end{array}$ & $\begin{array}{l}\text { Profil knjiga } \\
\text { d.o.o. }\end{array}$ \\
\hline $\begin{array}{l}\text { Svi bismo } \\
\text { trebali biti } \\
\text { feministi i } \\
\text { feministkinje } \\
\text { - Chima- } \\
\text { manda Ngozi } \\
\text { Adichie }\end{array}$ & $\begin{array}{l}\text { Eseji -- Američka } \\
\text { književnost } \\
\text { Feminizam -- Eseji } \\
\text { Žene -- Nigerija -- } \\
\text { Društveni uvjeti }\end{array}$ & 2019. & Esej & $\begin{array}{l}\text { Feminizam, } \\
\text { jednakost muš- } \\
\text { karaca i žena. }\end{array}$ & V.B.Z. \\
\hline
\end{tabular}




\section{C) Ljubavna djela}

Uspostavljanje posebnih odnosa s vršnjacima velik je dio života mladih i igra važnu ulogu u djelima fikcije za mlade, kao i za starije čitatelje. Otkrivanje uzbuđenja koje donosi romansa iznimno je privatno iskustvo. Čitanje signala potencijalnih ljubavnih partnera, razumijevanje vlastitih i tuđih osjećaja, odlučivanje kako i kada nešto poduzeti - sve to može biti izazovno za ljude bilo koje dobi (usp. Trupe 2006: 59). Ljubavna djela, barem prema rezultatima ovoga istraživanja, najčešće nisu isključivo ljubavna. Gotovo svako djelo sadrži elemente nekog drugog žanra - nadnaravno, kriminalističko, avanturističko i slično. Međutim, ono po čemu se može prepoznati da se radi o ljubavnom djelu jest neizbježna ljubavna priča (ili njih više).

U Tablici 3. prikazana su djela u kojima ljubavna priča i problemi koje ta priča donosi čine glavni dio, opisuju realne situacije mladih kada je u pitanju ljubav, a njihova glavna predmetna odrednica navodi da je u pitanju ljubavno djelo. Ta se djela bave temama poput ljubomore, problema sa samopouzdanjem, sudbine, neodlučnosti i prihvaćanja razlika.

Tablica 3. Ljubavna djela

\begin{tabular}{|l|l|l|l|l|l|}
\hline $\begin{array}{l}\text { Naslov knjige } \\
\text { i autor }\end{array}$ & $\begin{array}{l}\text { Predmetna } \\
\text { odrednica } \\
\text { knjižnice }\end{array}$ & $\begin{array}{l}\text { Godina } \\
\text { izdanja }\end{array}$ & $\begin{array}{l}\text { Vrsta } \\
\text { djela }\end{array}$ & $\begin{array}{l}\text { Tematska } \\
\text { obilježja djela }\end{array}$ & Nakladnik \\
\hline $\begin{array}{l}\text { Tajni leksi- } \\
\text { kon - Želimir } \\
\text { Hercigonja }\end{array}$ & $\begin{array}{l}\text { Ljubavni roman } \\
-- \text { Hrvatska knji- } \\
\text { ževnost }\end{array}$ & 2016. & Roman & $\begin{array}{l}\text { Školske simpatije } \\
\text { i ljubavi. }\end{array}$ & ALFA d.d. \\
\hline $\begin{array}{l}\text { I Sunce je zvi- } \\
\text { jezda - Nicola } \\
\text { Yoon }\end{array}$ & $\begin{array}{l}\text { Ljubavni roman } \\
\text {-- Američka knji- } \\
\text { ževnost }\end{array}$ & 2016. & Roman & $\begin{array}{l}\text { Sudbina, pro- } \\
\text { nalazak smisla } \\
\text { života, iseljeničke } \\
\text { obitelji - predra- } \\
\text { sude. }\end{array}$ & Znanje \\
\hline $\begin{array}{l}\text { I onda se } \\
\text { ponovno za- } \\
\text { ljubila - Nada } \\
\text { Mihoko- } \\
\text { vić-Kumrić }\end{array}$ & $\begin{array}{l}\text { Ljubavni roman } \\
- \text { ževnost } \\
\text { Humorvatska knji- } \\
\text { man -- Hrvatska } \\
\text { književnost }\end{array}$ & 2017. & Roman & $\begin{array}{l}\text { Ljubavne zavr- } \\
\text { zlame, kritika } \\
\text { društva, svijet } \\
\text { tajkuna i sebič- } \\
\text { nog bogaćenja, } \\
\text { materijalizma i } \\
\text { korupcije. }\end{array}$ & ALFA d.d. \\
\hline
\end{tabular}




\begin{tabular}{|c|c|c|c|c|c|}
\hline $\begin{array}{l}\text { Tajni leksikon } \\
3 \text { - Želimir } \\
\text { Hercigonja }\end{array}$ & $\begin{array}{l}\text { Ljubavni roman } \\
\text {-- Hrvatska knji- } \\
\text { ževnost }\end{array}$ & 2017. & Roman & $\begin{array}{l}\text { Ljubavne priče, } \\
\text { tinejdžerska nad- } \\
\text { metanja, ogova- } \\
\text { ranja, odrastanje } \\
\text { u nesređenim } \\
\text { uvjetima i kritič- } \\
\text { ko promatranje } \\
\text { svijeta oko sebe. }\end{array}$ & $\begin{array}{l}\text { Naklada } \\
\text { Ljevak }\end{array}$ \\
\hline $\begin{array}{l}\text { Svakoga dana } \\
\text { - David Levi- } \\
\text { than }\end{array}$ & $\begin{array}{l}\text { Ljubavni roman } \\
\text {-- Američka knji- } \\
\text { ževnost }\end{array}$ & 2017. & Roman & $\begin{array}{l}\text { Svakog jutra } \\
\text { 16-godišnjak se } \\
\text { budi u tijelu dru- } \\
\text { ge osobe slične } \\
\text { dobi; elementi } \\
\text { ljubavi. }\end{array}$ & $\begin{array}{l}\text { Lumen izda- } \\
\text { vaštvo }\end{array}$ \\
\hline $\begin{array}{l}\text { Gospođica } \\
\text { Knedlica - Ju- } \\
\text { lie Murphy }\end{array}$ & $\begin{array}{l}\text { Ljubavni roman } \\
\text {-- Američka knji- } \\
\text { ževnost } \\
\text { Humoristički ro- } \\
\text { man -- Američka } \\
\text { književnost }\end{array}$ & 2018. & Roman & $\begin{array}{l}\text { Tinejdžerski } \\
\text { roman o ljubavi } \\
\text { i stjecanju samo- } \\
\text { pouzdanja. }\end{array}$ & Znanje \\
\hline $\begin{array}{l}\text { Jedino sje- } \\
\text { ćanje Flore } \\
\text { Banks - Emily } \\
\text { Barr }\end{array}$ & $\begin{array}{l}\text { Ljubavni roman } \\
\text {-- Engleska knji- } \\
\text { ževnost } \\
\text { Psihološki roman } \\
\text {-- Engleska knji- } \\
\text { ževnost }\end{array}$ & 2018. & Roman & $\begin{array}{l}\text { Roman o tajnama } \\
\text { i lažima, ljubavi i } \\
\text { gubitku, hrabro- } \\
\text { sti i izdajama. }\end{array}$ & $\begin{array}{l}\text { Profil knjiga } \\
\text { d.o.o. }\end{array}$ \\
\hline $\begin{array}{l}\text { Kad bi lju- } \\
\text { bav mogla u } \\
\text { kutiju stati - } \\
\text { Adam Rajzl }\end{array}$ & $\begin{array}{l}\text { Ljubavna poezija } \\
\text {-- Hrvatska knji- } \\
\text { ževnost } \\
\text { Refleksivna po- } \\
\text { ezija -- Hrvatska } \\
\text { književnost }\end{array}$ & 2018. & Poezija & $\begin{array}{l}\text { Zbirka pjesama } \\
\text { za mlade, najvi- } \\
\text { še s ljubavnom } \\
\text { tematikom, ali i } \\
\text { temama obitelji, } \\
\text { odrastanja, okoli- } \\
\text { ša, pustolovina. }\end{array}$ & $\begin{array}{l}\text { Hrvatsko } \\
\text { društvo knji- } \\
\text { ževnika za } \\
\text { djecu i mlade }\end{array}$ \\
\hline $\begin{array}{l}\text { Leptir u } \\
\text { Karlinoj } \\
\text { kosi -- Josip } \\
\text { Balaško }\end{array}$ & $\begin{array}{l}\text { Refleksivna } \\
\text { poezija -- } \\
\text { Hrvatska } \\
\text { književnost } \\
\text { Humoristička } \\
\text { poezija -- } \\
\text { Hrvatska } \\
\text { književnost } \\
\end{array}$ & 2018. & Poezija & $\begin{array}{l}\text { Zbirka pjesama } \\
\text { o svakodnevnom } \\
\text { životu djece } \\
\text { kroz stihove u } \\
\text { rimi - obitelj, } \\
\text { ljubav, promjene, } \\
\text { pustolovine. }\end{array}$ & $\begin{array}{l}\text { Hrvatsko } \\
\text { društvo } \\
\text { književnika } \\
\text { za djecu i } \\
\text { mlade }\end{array}$ \\
\hline
\end{tabular}




\section{D) Povijesna djela}

Kada su u pitanju povijesna djela, osobito ona za mlade, pokazalo se da je mnogima bitan preduvjet za čitanje takvih knjiga ne samo točnost povijesnih podataka (što je bitna karakteristika takve književnosti), već dobro opisani i uvjerljivi likovi s kojima se mladi mogu identificirati. Autoru je ponekad izazov ostati vjeran povijesnim činjenicama uz paralelno razvijanje likova u skladu s kulturnim normama razdoblja koje opisuje (usp. Trupe 2006: 115).

Ono što je provedeno istraživanje pokazalo jest da u Hrvatskoj ne postoji mnogo novijih djela koja su u osnovi povijesna. Činjenica je zapravo da je takvih djela malo, a ona koja su objavljena često imaju izraženije karakteristike drugih žanrova poput npr. fantastičnog ili religijskog. Ipak, tema koja se pojavljuje u povijesnim romanima često je rat. U konkretnom slučaju djela iz hrvatske književnosti spominje se Domovinski rat i povijest svijeta - istražuju se veze koje su stvarali ljudi, trgovinska razmjena, bolesti, ratovi, religije, pustolovine, znanost, tehnologija i sl. kao što je prikazano u Tablici 4.

Tablica 4. Povijesna djela

\begin{tabular}{|l|l|l|l|l|l|}
\hline $\begin{array}{l}\text { Naslov } \\
\text { knjige i } \\
\text { autor }\end{array}$ & $\begin{array}{l}\text { Predmetna } \\
\text { odrednica knjižnice }\end{array}$ & $\begin{array}{l}\text { Godina } \\
\text { izdanja }\end{array}$ & $\begin{array}{l}\text { Vrsta } \\
\text { djela }\end{array}$ & $\begin{array}{l}\text { Tematska } \\
\text { obilježja djela }\end{array}$ & Nakladnik \\
\hline $\begin{array}{l}\text { Do nakraj } \\
\text { svijeta - Lo- } \\
\text { uis de Wohl }\end{array}$ & $\begin{array}{l}\text { Povijesni roman -- } \\
\text { Engleska književnost } \\
\text { Religiozni roman -- } \\
\text { Engleska književnost }\end{array}$ & 2017. & Roman & $\begin{array}{l}\text { Roman o misio- } \\
\text { narskom načinu } \\
\text { života. }\end{array}$ & Verbum \\
\hline $\begin{array}{l}\text { Runo- Ante } \\
\text { Gugo }\end{array}$ & $\begin{array}{l}\text { Ratne pripovijetke -- } \\
\text { Hrvatska književnost }\end{array}$ & 2018. & Roman & $\begin{array}{l}\text { Bijeg prognanih } \\
\text { Hrvata, zbivanja } \\
\text { početkom Do- } \\
\text { movinskog rata. }\end{array}$ & $\begin{array}{l}\text { Despot } \\
\text { Infinitus } \\
\text { d.o.o. }\end{array}$ \\
\hline $\begin{array}{l}\text { Putovi svi- } \\
\text { le- Peter } \\
\text { Frankopan }\end{array}$ & $\begin{array}{l}\text { Imperijalizam -- Po- } \\
\text { vijest } \\
\text { Svila -- Trgovački } \\
\text { putevi -- Povijest } \\
\text { Kulturni dodiri -- } \\
\text { Europa -- Kina } \\
\text { Kultura i društvo -- } \\
\text { Sociološko gledište }\end{array}$ & 2018. & Roman & $\begin{array}{l}\text { Povijest svijeta, } \\
\text { ispreplitanje ra- } \\
\text { zličitih naroda, } \\
\text { carstva i kontine- } \\
\text { nata. }\end{array}$ & $\begin{array}{l}\text { Školska } \\
\text { knjiga }\end{array}$ \\
\hline
\end{tabular}




\begin{tabular}{|c|c|c|c|c|c|}
\hline $\begin{array}{l}\text { Corto Mal- } \\
\text { tese - Ekva- } \\
\text { torija - Juan } \\
\text { Díaz Cana- } \\
\text { les, Rubén } \\
\text { Pellejero }\end{array}$ & Strip & 2018. & Strip & $\begin{array}{l}\text { 1911. godina; put } \\
\text { glavnog lika iz } \\
\text { Venecije u afrič- } \\
\text { ku ekvatorijalnu } \\
\text { prašumu u po- } \\
\text { trazi za „zrcalom } \\
\text { sećenika Jvana“ }\end{array}$ & Bookglobe \\
\hline
\end{tabular}

\section{E) Religijska djela}

Adolescencija je razdoblje propitivanja i suočavanja s vrijednostima s kojima smo odrasli, kao i razdoblje usvajanja vlastitih uvjerenja. Mladi ljudi s jakim vjerskim uvjerenjima u razdoblju adolescencije počinju shvaćati svoje razlike u odnosu na prijatelje, na način na koji tu različitost nisu shvaćali u djetinjstvu. Najočitiji je razlog dodatnog pritiska na propitivanje njihove vrijednosti razvijanje svijesti o seksualnosti, ali i veća neovisnost. Također, još je jedan čimbenik vršnjački pritisak koji čini moralne izbore tinejdžera problematičnijima nego u mlađim godinama (usp. Trupe 2006: 9). U Hrvatskoj se većina stanovništva (usp. Državni zavod za statistiku 2011) izjasnila da su katolici. Vjerojatno je to razlog zbog kojega se i pišu knjige u katoličkom duhu. Iz istraživanja je vidljivo da se u takvim djelima najčešće opisuju životni putevi časnih sestara i svećenika, prisutne su i ljubavne priče, savjeti za mlade te opisivanje odnosa prema životu i smrti. Zanimljivo je istaknuti da se u nekoliko knjiga autori izravno obraćaju mladima te im šalju određene poruke i riječi kao što prikazuje Tablica 5.

Tablica 5. Religijska djela

\begin{tabular}{|l|l|l|l|l|l|}
\hline $\begin{array}{l}\text { Naslov knjige } \\
\text { i autor }\end{array}$ & $\begin{array}{l}\text { Predmetna } \\
\text { odrednica } \\
\text { knjižnice }\end{array}$ & $\begin{array}{l}\text { Godina } \\
\text { izdanja }\end{array}$ & $\begin{array}{l}\text { Vrsta } \\
\text { djela }\end{array}$ & $\begin{array}{l}\text { Tematska } \\
\text { obilježja djela }\end{array}$ & Nakladnik \\
\hline $\begin{array}{l}365 \text { malih } \\
\text { priča za } \\
\text { dušu - Bruno } \\
\text { Ferrero }\end{array}$ & $\begin{array}{l}\text { Duhovne priče } \\
\text {-- Talijanska knji- } \\
\text { ževnost }\end{array}$ & 2016. & $\begin{array}{l}\text { Zbirka } \\
\text { priča }\end{array}$ & $\begin{array}{l}\text { Priče popraćene } \\
\text { sažetim mu- } \\
\text { drim mislima. }\end{array}$ & Salesiana \\
\hline $\begin{array}{l}\text { Oslobođeni } \\
\text { za ljubav - } \\
\text { Matt Fradd }\end{array}$ & $\begin{array}{l}\text { Pornografija -- Suz- } \\
\text { bijanje i kontrola -- } \\
\text { Teološko gledište }\end{array}$ & 2016. & $\begin{array}{l}\text { Zbirka } \\
\text { svjedo- } \\
\text { čanstava }\end{array}$ & $\begin{array}{l}\text { Oslobođenje od } \\
\text { ovisnosti o por- } \\
\text { nografiji. }\end{array}$ & Verbum \\
\hline $\begin{array}{l}\text { Sovica dar i } \\
\text { šest dobrih } \\
\text { anđela - Že- } \\
\text { limir Herci- } \\
\text { gonja }\end{array}$ & $\begin{array}{l}\text { Igrokazi -- Hrvat- } \\
\text { ska književnost }\end{array}$ & 2016. & Igrokaz & Badnjak, Božić & $\begin{array}{l}\text { Hrvatsko } \\
\text { društvo } \\
\text { književnika } \\
\text { za djecu i } \\
\text { mlade }\end{array}$ \\
\hline
\end{tabular}




\begin{tabular}{|c|c|c|c|c|c|}
\hline $\begin{array}{l}\text { Baraka koja } \\
\text { je nahranila } \\
\text { milijun dje- } \\
\text { ce - Magnus } \\
\text { MacFarla- } \\
\text { ne-Barrow } \\
\end{array}$ & $\begin{array}{l}\text { Humanitarne orga- } \\
\text { nizacije -- Zemlje u } \\
\text { razvoju } \\
\text { Humanitarna po- } \\
\text { moć -- Međuna- } \\
\text { rodne organizacije }\end{array}$ & 2016. & Roman & $\begin{array}{l}\text { Humanost, siro- } \\
\text { maštvo }\end{array}$ & Verbum \\
\hline $\begin{array}{l}\text { Leopoldova } \\
\text { uljanica - } \\
\text { Dubravka } \\
\text { Rovičanac }\end{array}$ & $\begin{array}{l}\text { Biografske priče } \\
\text {-- Hrvatska knji- } \\
\text { ževnost } \\
\text { Religiozne priče } \\
\text {-- Hrvatska knji- } \\
\text { ževnost }\end{array}$ & 2016. & $\begin{array}{l}\text { Zbirka } \\
\text { priča }\end{array}$ & $\begin{array}{l}\text { Spoznaja Boga, } \\
\text { kazna za uboj- } \\
\text { stvo. }\end{array}$ & Glas Koncila \\
\hline $\begin{array}{l}\text { YOUCAT Bi- } \\
\text { blija za mlade } \\
\text { - prevoditelj } \\
\text { Franjo Fran- } \\
\text { kopan Velić }\end{array}$ & $\begin{array}{l}\text { Biblija -- Mladi -- } \\
\text { Čitanje } \\
\text { Biblija za mlade -- } \\
\text { Priručnik }\end{array}$ & 2016. & Biblija & $\begin{array}{l}\text { Osobna iskustva } \\
\text { i svjedočanstva } \\
\text { mladih. }\end{array}$ & Verbum \\
\hline $\begin{array}{l}\text { Sveta potvrda } \\
\text { - Papa Franjo } \\
\text { - Jorge Mario } \\
\text { Bergoglio } \\
\end{array}$ & & 2016. & Priručnik & $\begin{array}{l}\text { Sakrament svete } \\
\text { potvrde i darovi } \\
\text { Duha Svetoga. }\end{array}$ & Verbum \\
\hline $\begin{array}{l}\text { Docat - Arnd } \\
\text { Kuppers, Pe- } \\
\text { ter Schallen- } \\
\text { berg }\end{array}$ & $\begin{array}{l}\text { Crkveni socijalni } \\
\text { nauk -- Priručnici }\end{array}$ & 2016. & $\begin{array}{l}\text { Kateki- } \\
\text { zam }\end{array}$ & $\begin{array}{l}\text { Aktualna druš- } \\
\text { tvena pitanja, } \\
\text { međusobno } \\
\text { razumijevanje i } \\
\text { poštovanje. }\end{array}$ & Verbum \\
\hline $\begin{array}{l}\text { Majka Tere- } \\
\text { zija-Didier } \\
\text { Chardez }\end{array}$ & $\begin{array}{l}\text { Majka Terezija, } \\
\text { redovnica -- Bio- } \\
\text { grafija } \\
\text { Strip }\end{array}$ & 2016. & Strip & $\begin{array}{l}\text { Priča o ženi } \\
\text { snažne vjere i } \\
\text { velike svetosti. }\end{array}$ & Verbum \\
\hline $\begin{array}{l}\text { Franjine riječi } \\
\text { Mladima - } \\
\text { papa Franjo } \\
\text { Jorge Mario } \\
\text { Bergoglio } \\
\end{array}$ & & 2016. & Priručnik & $\begin{array}{l}\text { Važnost i dra- } \\
\text { gocjenost svih } \\
\text { ljudi. }\end{array}$ & Salesiana \\
\hline $\begin{array}{l}\text { Biblijski kom- } \\
\text { pas - Edward } \\
\text { Sri }\end{array}$ & $\begin{array}{l}\text { Biblia -- Tumačenje } \\
\text { Biblia -- Priručnik }\end{array}$ & 2016. & Priručnik & $\begin{array}{l}\text { Osobno prouča- } \\
\text { vanje Biblije. }\end{array}$ & Verbum \\
\hline $\begin{array}{l}\text { Četiri zida } \\
\text {-- Elena Jur- } \\
\text { ković }\end{array}$ & $\begin{array}{l}\text { Autobiografska } \\
\text { proza -- Hrvatska } \\
\text { književnost }\end{array}$ & 2017. & Roman & $\begin{array}{l}\text { Osobni razgo- } \\
\text { vor s Bogom, } \\
\text { najintimnije } \\
\text { emocije. }\end{array}$ & Figulus \\
\hline
\end{tabular}




\begin{tabular}{|c|c|c|c|c|c|}
\hline $\begin{array}{l}\text { Za pet sati ću } \\
\text { vidjeti Isusa - } \\
\text { Jacques Fesch }\end{array}$ & $\begin{array}{l}\text { Dnevnička proza } \\
\text {-- Francuska knji- } \\
\text { ževnost } \\
\text { Obraćenje -- Svje- } \\
\text { dočanstva }\end{array}$ & 2017. & Roman & $\begin{array}{l}\text { Spoznaja Boga, } \\
\text { kazna za uboj- } \\
\text { stvo. }\end{array}$ & Verbum \\
\hline $\begin{array}{l}\text { Punina rado- } \\
\text { sti - Majka } \\
\text { Elvira }\end{array}$ & $\begin{array}{l}\text { Evangelizacija } \\
\text {-- Mladež -- Vrijed- } \\
\text { nosti } \\
\text { Duhovne vježbe -- } \\
\text { Kršćanstvo } \\
\end{array}$ & 2017. & Roman & $\begin{array}{l}\text { Preobraženje } \\
\text { života uz prisu- } \\
\text { stvo Boga. }\end{array}$ & Verbum \\
\hline $\begin{array}{l}\text { Frcanje iskri } \\
\text { - knjiga za } \\
\text { Krizmu - } \\
\text { Stephan Sigg }\end{array}$ & $\begin{array}{l}\text { Potvrda (Sakra- } \\
\text { ment) -- Razma- } \\
\text { tranja } \\
\text { Duh Sveti -- Otaj- } \\
\text { stveni značaj } \\
\text { Mladež -- Vjerski } \\
\text { odgoj }\end{array}$ & 2017. & Priručnik & $\begin{array}{l}\text { Duh Sveti, } \\
\text { sakrament kriz- } \\
\text { me. }\end{array}$ & $\begin{array}{l}\text { Kršćanska } \\
\text { sadašnjost }\end{array}$ \\
\hline $\begin{array}{l}\text { Poruke mla- } \\
\text { dima - Papa } \\
\text { Franjo Jorge } \\
\text { Mario Bergo- } \\
\text { glio }\end{array}$ & $\begin{array}{l}\text { Duhovni život } \\
\text {-- Kršćanstvo -- } \\
\text { Rječnici }\end{array}$ & 2017. & $\begin{array}{l}\text { Zbirka } \\
\text { poruka i } \\
\text { misli }\end{array}$ & $\begin{array}{l}\text { Zanimanja, } \\
\text { potrebe i očeki- } \\
\text { vanja mladih. }\end{array}$ & $\begin{array}{l}\text { Kršćanska } \\
\text { sadašnjost }\end{array}$ \\
\hline $\begin{array}{l}\text { Uskrsnuće - } \\
\text { upute za upo- } \\
\text { rabu - Fabrice } \\
\text { Hadjadj } \\
\end{array}$ & $\begin{array}{l}\text { Uskrsnuće -- } \\
\text { Osnovni pojmovi } \\
\text { Vjera -- Svjedočan- } \\
\text { stva }\end{array}$ & 2017. & Priručnik & $\begin{array}{l}\text { Utjecaj uskr- } \\
\text { snuća na ljude. }\end{array}$ & Verbum \\
\hline $\begin{array}{l}\text { Cesta sunca } \\
\text { - Francesco } \\
\text { Lorenzi }\end{array}$ & $\begin{array}{l}\text { Lorenzi, Francesco } \\
\text {-- Autobiografija } \\
\text { Sun -- Autobiograf- } \\
\text { ski prilozi } \\
\text { Rock glazbenici } \\
\text {-- Italija -- Autobi- } \\
\text { ografije }\end{array}$ & 2017. & Roman & $\begin{array}{l}\text { Obraćenje } \\
\text { rock-benda, } \\
\text { ovisnost o dro- } \\
\text { gi, alkoholu i } \\
\text { seksu. }\end{array}$ & $\begin{array}{l}\text { Naklada } \\
\text { Benedikta }\end{array}$ \\
\hline $\begin{array}{l}\text { Upravljanje } \\
\text { vremenom } \\
\text { za katolike - } \\
\text { Dave Durand }\end{array}$ & $\begin{array}{l}\text { Upravljanje vreme- } \\
\text { nom -- Religijski } \\
\text { aspekti - Kršćan- } \\
\text { stvo } \\
\text { Duhovni život -- } \\
\text { Katolička crkva } \\
\end{array}$ & 2017. & Priručnik & $\begin{array}{l}\text { Odnos s obitelji } \\
\text { i Bogom }\end{array}$ & Verbum \\
\hline $\begin{array}{l}\text { Što ti želim } \\
\text { za krizmu - } \\
\text { Stephan Sigg }\end{array}$ & $\begin{array}{l}\text { Mladež -- Način } \\
\text { života } \\
\text { Život -- Religijski } \\
\text { aspekti -- } \\
\text { Kršćanstvo } \\
\end{array}$ & 2017. & Priručnik & $\begin{array}{l}\text { Ljudske i kr- } \\
\text { šćanske kreposti } \\
\text { i darovi Duha } \\
\text { Svetoga. }\end{array}$ & $\begin{array}{l}\text { Kršćanska } \\
\text { sadašnjost }\end{array}$ \\
\hline
\end{tabular}


Ivana MARTINOVIĆ, Ivona GRGIĆ, Elizabeta KOTROMANOVIĆ: UŽITAK U ČITANJU: TEME U LITERATURI...

\begin{tabular}{|l|l|l|l|l|l|}
\hline $\begin{array}{l}365 \text { malih } \\
\text { priča za dušu } \\
2-\text { Bruno } \\
\text { Ferrero }\end{array}$ & $\begin{array}{l}\text { Duhovne priče } \\
-- \text { Talijanska knji- } \\
\text { ževnost }\end{array}$ & 2018. & $\begin{array}{l}\text { Zbirka } \\
\text { priča }\end{array}$ & $\begin{array}{l}\text { Priče popraćene } \\
\text { sažetim mu- } \\
\text { drim mislima. }\end{array}$ & Salesiana \\
\hline
\end{tabular}

\section{F) Kriminalistička djela i trileri}

Mnogi čitatelji vole misterije, uživaju u napetosti stvorenoj u situaciji kada je zločin počinjen i u istrazi do koje dolazi nakon zločina. Takva djela čitatelju daju rješenje; onakvo kakvo je rijetko i teško ga je dobiti u stvarnom životu gdje dobro i zlo nije toliko jasno odvojeno. Rješavanje misterija zajedno s likovima i praćenje razvoja radnje, pokušaj razumijevanja motiva iza kojih stoje mnogi zločini, uočavanje kompleksnosti likova otkrivanjem njihovih tajni i rješavanjem zagonetki, samo su neki od razloga zašto su kriminalistička i psihološka djela popularna u literaturi za mlade i odrasle (usp. Trupe 2006: 99).

Istraživanjem je pronađeno nekoliko djela u kojima se pojavljuju već spomenuti elementi, ali i nove karakteristike koje roman čine misterioznim. Često se isprepliću s djelima nadnaravne karakteristike, a donose i ljubavne priče, priče o prijateljstvu ili probleme u odrastanju, što su teme uvelike obuhvaćene u djelima kojima se opisuju realistične životne situacije i problemi mladih kao što je prikazano u Tablici 6 .

Tablica 6. Kriminalistička djela i trileri

\begin{tabular}{|c|c|c|c|c|c|}
\hline $\begin{array}{l}\text { Naslov knjige } \\
\text { i autor }\end{array}$ & $\begin{array}{l}\text { Predmetna } \\
\text { odrednica } \\
\text { knjižnice }\end{array}$ & $\begin{array}{l}\text { Godina } \\
\text { izdanja }\end{array}$ & $\begin{array}{l}\text { Vrsta } \\
\text { djela }\end{array}$ & \begin{tabular}{|l|} 
Tematska \\
obilježja djela
\end{tabular} & Nakladnik \\
\hline $\begin{array}{l}\text { Lopovska } \\
\text { uspavanka - } \\
\text { Pavao Pavličić }\end{array}$ & $\begin{array}{l}\text { Kriminalistički } \\
\text { roman -- Hrvat- } \\
\text { ska književnost }\end{array}$ & 2018. & Roman & $\begin{array}{l}\text { Likovi romana } \\
\text { „Trojica u Trnju“ i } \\
\text { „Petlja“ susreću se } \\
\text { s novim zaplete- } \\
\text { nim slučajem. }\end{array}$ & $\begin{array}{l}\text { Mozaik } \\
\text { knjiga }\end{array}$ \\
\hline $\begin{array}{l}\text { Tajna najbo- } \\
\text { ljih prijatelja } \\
\text { - Hrvoje Ko- } \\
\text { vačević }\end{array}$ & $\begin{array}{l}\text { Kriminalistički } \\
\text { roman -- Hrvat- } \\
\text { ska književnost }\end{array}$ & 2018. & Roman & $\begin{array}{l}\text { Niz opasnih i ne- } \\
\text { ugodnih situacija } \\
\text { u kojima se nađu } \\
\text { glavni lik i njegovi } \\
\text { prijatelji; tajne } \\
\text { među prijateljima. }\end{array}$ & $\begin{array}{l}\text { Školska } \\
\text { knjiga }\end{array}$ \\
\hline
\end{tabular}




\begin{tabular}{|c|c|c|c|c|c|}
\hline $\begin{array}{l}\text { Lažljivac } \\
\text { među nama } \\
\text { - Karen M. } \\
\text { McManus }\end{array}$ & $\begin{array}{l}\text { Triler -- Američ- } \\
\text { ka književnost } \\
\text { Psihološki ro- } \\
\text { man -- Američ- } \\
\text { ka književnost }\end{array}$ & 2018. & Roman & $\begin{array}{l}\text { Atmosfera u školi } \\
\text { potresenoj tragič- } \\
\text { nim događajem } \\
\text { - smrti dječaka od } \\
\text { alergijske reakcije } \\
\text { gdje su svi poten- } \\
\text { cijalno osumnjiče- } \\
\text { ni i svi pokušavaju } \\
\text { saznati što se do- } \\
\text { godilo. }\end{array}$ & $\begin{array}{l}\text { Profil knjiga } \\
\text { d.o.o. }\end{array}$ \\
\hline
\end{tabular}

\section{G) Pustolovna djela}

Pustolovinu u svakodnevnom životu možemo definirati kao nešto izvanredno; neobičan, nenadan i uzbudljiv događaj u životu pojedinca (Hrvatska enciklopedija 2019). Pisanje i čitanje o raznim pustolovinama nije novost, posebice u zapadnom svijetu. Vjeruje se da susretanje s ekstremnim uvjetima donosi istinsku čvrstoću i inteligenciju ljudi. U mnogim pustolovnim romanima od mladih se ljudi zahtijeva da žive svojim umom u izazovima, udaljeni od društva i norme. Pustolovina često može sadržavati nadnaravne elemente ili slike distopijske budućnosti. Također, može uključivati putovanje u prošlost, neovisno o tome koliko je činjenično točno ta prošlost opisana. Pustolovina uključuje i elemente kriminalističkog romana budući da nerijetko likovi moraju otkrivati razne misterije i tajne kako bi njihova avantura bila potpuna. Uz dodatne elemente ljubavi, prijateljstva, odrastanja i sl., pustolovina se može naći u gotovo svakome žanru (usp. Trupe 2006: 217).

$\mathrm{U}$ nastavku donosimo naslove i autore knjiga pronađene $\mathrm{u}$ istraživanju koje se mogu smatrati pustolovnim djelima.

Tablica 7. Pustolovna djela

\begin{tabular}{|l|l|l|l|l|l|}
\hline $\begin{array}{l}\text { Naslov knjige } \\
\text { i autor }\end{array}$ & $\begin{array}{l}\text { Predmetna } \\
\text { odrednica } \\
\text { knjižnice }\end{array}$ & $\begin{array}{l}\text { Godina } \\
\text { izdanja }\end{array}$ & $\begin{array}{l}\text { Vrsta } \\
\text { djela }\end{array}$ & $\begin{array}{l}\text { Tematska } \\
\text { obilježja djela }\end{array}$ & Nakladnik \\
\hline $\begin{array}{l}\text { Kradljivac } \\
\text { luridija- Bo- } \\
\text { bbie Peers }\end{array}$ & $\begin{array}{l}\text { Pustolovni roman } \\
\text {-- Norveška knji- } \\
\text { ževnost }\end{array}$ & 2016. & Roman & $\begin{array}{l}\text { Glavni junak } \\
\text { sa sposobno- } \\
\text { šću razbijanja } \\
\text { sifri; život ispu- } \\
\text { njen tajnama } \\
\text { i strahom te } \\
\text { dramatičnim } \\
\text { okolnostima. }\end{array}$ & $\begin{array}{l}\text { Naklada } \\
\text { Ljevak }\end{array}$ \\
\hline
\end{tabular}




\begin{tabular}{|c|c|c|c|c|c|}
\hline $\begin{array}{l}\text { Ottolina i } \\
\text { žuta mačka - } \\
\text { Chris Riddell }\end{array}$ & $\begin{array}{l}\text { Pustolovni roman } \\
\text {-- Engleska knji- } \\
\text { ževnost }\end{array}$ & 2017. & Roman & \begin{tabular}{|l|} 
Djevojčica \\
Ottolina i njezin \\
prijatelj - neo- \\
bičan i dlakav \\
stvor pokušava- \\
ju riješiti zago- \\
netke vlastitim \\
sposobnostima.
\end{tabular} & $\begin{array}{l}\text { Profil knjiga } \\
\text { d.o.o. }\end{array}$ \\
\hline $\begin{array}{l}\text { Lov na bla- } \\
\text { go - Jim M. } \\
\text { Evans }\end{array}$ & $\begin{array}{l}\text { Pustolovni roman } \\
\text {-- Engleska knji- } \\
\text { ževnost } \\
\text { Duhovni roman } \\
\text {-- Engleska knji- } \\
\text { ževnost }\end{array}$ & 2017. & Roman & $\begin{array}{l}\text { Razrješavanje } \\
\text { tajne uz pomoć } \\
\text { molitve, vjere } \\
\text { i poznavanja } \\
\text { Biblije. }\end{array}$ & Kristofori \\
\hline $\begin{array}{l}\text { Tajni portal - } \\
\text { Bobbie Peers }\end{array}$ & $\begin{array}{l}\text { Pustolovni roman } \\
\text {-- Norveška knji- } \\
\text { ževnost }\end{array}$ & 2017. & Roman & $\begin{array}{l}\text { Priča o dječaku } \\
\text { s čudesnom } \\
\text { sposobnošću } \\
\text { razbijanja šifri; } \\
\text { elementi prija- } \\
\text { teljstva i obitelji. }\end{array}$ & $\begin{array}{l}\text { Naklada } \\
\text { Ljevak }\end{array}$ \\
\hline $\begin{array}{l}\text { Dlakava lju- } \\
\text { bav - Nives } \\
\text { Madunić } \\
\text { Barišić } \\
\end{array}$ & $\begin{array}{l}\text { Pustolovni roman } \\
\text {-- Hrvatska knji- } \\
\text { ževnost }\end{array}$ & 2018. & Roman & $\begin{array}{l}\text { Priča o likovima } \\
\text { (životinjama) } \\
\text { koji rješavaju } \\
\text { slučaj. }\end{array}$ & $\begin{array}{l}\text { Mozaik } \\
\text { knjiga }\end{array}$ \\
\hline $\begin{array}{l}\text { Putujući } \\
\text { cirkus - Da- } \\
\text { vid Homel i } \\
\text { Marie-Louise } \\
\text { Gay }\end{array}$ & $\begin{array}{l}\text { Pustolovni roman } \\
\text {-- Kanadska knji- } \\
\text { ževnost }\end{array}$ & 2018. & Roman & $\begin{array}{l}\text { Avanturistički } \\
\text { roman za djecu } \\
\text { i mlade čija se } \\
\text { radnja u najve- } \\
\text { ćem dijelu odvi- } \\
\text { ja u Hrvatskoj. }\end{array}$ & Naklada Val \\
\hline $\begin{array}{l}\text { Priče iz cije- } \\
\text { loga svijeta - } \\
\text { grupa autora } \\
\text { (prijevod } \\
\text { Anda Bukvić } \\
\text { Pažin) }\end{array}$ & $\begin{array}{l}\text { Narodne priče } \\
\text {-- Svjetska književ- } \\
\text { nost }\end{array}$ & 2018. & $\begin{array}{l}\text { Narodne } \\
\text { priče }\end{array}$ & $\begin{array}{l}\text { Dvadeset ilu- } \\
\text { striranih priča } \\
\text { sa svih kontine- } \\
\text { nata. }\end{array}$ & Znanje \\
\hline $\begin{array}{l}\text { U službi or- } \\
\text { bulatora - Bo- } \\
\text { bbie Peers }\end{array}$ & $\begin{array}{l}\text { Pustolovni roman } \\
\text {-- Norveška knji- } \\
\text { ževnost }\end{array}$ & 2018. & Roman & $\begin{array}{l}\text { Dječak s čude- } \\
\text { snom sposob- } \\
\text { nošću razbijanja } \\
\text { šifri; elementi } \\
\text { pustolovine, } \\
\text { prijateljstva i } \\
\text { suočavanja s } \\
\text { opasnostima. }\end{array}$ & $\begin{array}{l}\text { Naklada } \\
\text { Ljevak }\end{array}$ \\
\hline
\end{tabular}




\section{H) Ostala djela}

Romani mogu imati različite tonove te se autorova namjera razlikuje od djela do djela. Shodno tome, djelo može biti sentimentalno, satirično ili humoristično. Takva djela, odnosno romani, koje nije moguće svrstati u kategorije koje su ranije navedene, svrstani su u kategoriju ostalih djela. U tu kategoriju pripadaju različiti humoristični romani. Oni su često prožeti motivima raznih drugih romana, pa su takvi romani uz humor, također romantične, obiteljske ili prijateljske tematike (usp. Proleksis enciklopedija 2019). Radnja je u takvim djelima obično napisana tako da su u prvom planu humoristične situacije koje se događaju likovima.

Nadalje, u kategoriji ostalih djela pojavljuje se vodič o popularnoj računalnoj igrici za mlade - Fortnite - koji sadrži savjete i upute o igranju. U popisu ostalih djela za mlade nalazi se i jedno referentno djelo, a to je enciklopedija, na temu anatomije ljudskog tijela. Zatim, među ostalim djelima nalazi se i priručnik koji se svrstava među djela za mlade. Priručnik donosi svojevrsne treninge za mlade o samopoštovanju i motivaciji. Naposljetku, tu je svrstan i praktičan savjetnik u kojem se predstavlja važnost igre u odgoju djece, kao što je vidljivo u Tablici 8.

Tablica 8. Ostala djela

\begin{tabular}{|l|l|l|l|l|l|}
\hline $\begin{array}{l}\text { Naslov knjige } \\
\text { i autor }\end{array}$ & $\begin{array}{l}\text { Predmetna } \\
\text { odrednica } \\
\text { knjižnice }\end{array}$ & $\begin{array}{l}\text { Godina } \\
\text { izdanja }\end{array}$ & $\begin{array}{l}\text { Vrsta } \\
\text { djela }\end{array}$ & $\begin{array}{l}\text { Tematska } \\
\text { obilježja djela }\end{array}$ & Nakladnik \\
\hline $\begin{array}{l}\text { Tko se to } \\
\text { tamo gura } \\
\text { - Zoran Pon- } \\
\text { grašić }\end{array}$ & $\begin{array}{l}\text { Humoristički ro- } \\
\text { man -- Hrvatska } \\
\text { književnost }\end{array}$ & 2016. & Roman & $\begin{array}{l}\text { Zgode i nezgode } \\
\text { jednojajčanih } \\
\text { blizanaca. }\end{array}$ & $\begin{array}{l}\text { Hrvatsko } \\
\text { društvo knji- } \\
\text { ževnika za } \\
\text { djecu i mlade }\end{array}$ \\
\hline $\begin{array}{l}\text { Sretni dani - } \\
\text { Miro Gavran }\end{array}$ & $\begin{array}{l}\text { Humoristički ro- } \\
\text { man -- Hrvatska } \\
\text { književnost }\end{array}$ & 2016. & Roman & $\begin{array}{l}\text { Priča o želji ti- } \\
\text { nejdžera za kom- } \\
\text { pletnom obitelji, } \\
\text { teme prijateljstva } \\
\text { i školskih sim- } \\
\text { patija. }\end{array}$ & Mozaik knjiga \\
\hline $\begin{array}{l}\text { Doktor Prok- } \\
\text { tor i velika } \\
\text { krađa zlata - } \\
\text { Jo Nesbo }\end{array}$ & $\begin{array}{l}\text { Humoristički ro- } \\
\text { man -- Švedska } \\
\text { književnost }\end{array}$ & 2016. & Roman & $\begin{array}{l}\text { Knjiga o spa- } \\
\text { silačkoj misiji } \\
\text { junaka - nastoje } \\
\text { vratiti oteto zlato } \\
\text { u Norvešku igra- } \\
\text { njem na nogo- } \\
\text { metnom terenu. }\end{array}$ & Fokus komu- \\
nikacije
\end{tabular}




\begin{tabular}{|c|c|c|c|c|c|}
\hline $\begin{array}{l}\text { Bajka o šeširu } \\
\text { koji je imao } \\
\text { čovjeka - } \\
\text { Nena Lončar }\end{array}$ & \begin{tabular}{|l|} 
Humorističke \\
priče -- Hrvat- \\
ska književnost \\
Alegorijske priče \\
-- Hrvatska knji- \\
ževnost \\
\end{tabular} & 2017. & $\begin{array}{l}\text { Slikov- } \\
\text { nica }\end{array}$ & $\begin{array}{l}\text { Alegorija o izvr- } \\
\text { nutim vrijedno- } \\
\text { stima. }\end{array}$ & $\begin{array}{l}\text { Hrvatsko } \\
\text { društvo knji- } \\
\text { ževnika za } \\
\text { djecu i mlade }\end{array}$ \\
\hline $\begin{array}{l}\text { Gregov dnev- } \\
\text { nik - Rodrick } \\
\text { rastura, } \\
\text { 2.knjiga - Jeff } \\
\text { Kinney } \\
\end{array}$ & \begin{tabular}{|l|} 
Humoristički \\
roman -- Ame- \\
rička književnost
\end{tabular} & 2017. & Strip & $\begin{array}{l}\text { Tajna kobnog } \\
\text { događaja s ljetnih } \\
\text { praznika, brat } \\
\text { izdaje tajnu jav- } \\
\text { nosti. }\end{array}$ & Algoritam \\
\hline $\begin{array}{l}\text { Gregov dnev- } \\
\text { nik: Dugo } \\
\text { putovanje - } \\
\text { Jeff Kinney } \\
\end{array}$ & $\begin{array}{l}\text { Humoristički } \\
\text { roman -- Ame- } \\
\text { rička književnost }\end{array}$ & 2018. & Strip & $\begin{array}{l}\text { Obiteljsko puto- } \\
\text { vanje popraćeno } \\
\text { urnebesnim do- } \\
\text { godovštinama. } \\
\end{array}$ & Mozaik knjiga \\
\hline $\begin{array}{l}\text { Darcy Bur- } \\
\text { dock - Jasno } \\
\text { kao dan } \\
\text { - Laura Doc- } \\
\text { krill }\end{array}$ & $\begin{array}{l}\text { Humoristički ro- } \\
\text { man -- Engleska } \\
\text { književnost }\end{array}$ & 2018. & Roman & $\begin{array}{l}\text { Suočavanje s pro- } \\
\text { blemima: škola, } \\
\text { baka, kućni lju- } \\
\text { bimac. }\end{array}$ & Mozaik knjiga \\
\hline $\begin{array}{l}\text { Loš tata-Da- } \\
\text { vid Walliams }\end{array}$ & \begin{tabular}{|l|} 
Humoristički ro- \\
man -- Engleska \\
književnost
\end{tabular} & 2018. & Roman & $\begin{array}{l}\text { Borba oca i sina } \\
\text { protiv nepravde i } \\
\text { zlikovaca. }\end{array}$ & Mozaik knjiga \\
\hline $\begin{array}{l}\text { Gregov dnev- } \\
\text { nik: Nezgoda } \\
\text { za nezgodom } \\
\text { - Jeff Kinney } \\
\end{array}$ & $\begin{array}{l}\text { Humoristički } \\
\text { roman -- Ame- } \\
\text { rička književnost }\end{array}$ & 2018. & Roman & $\begin{array}{l}\text { Izdaja najboljeg } \\
\text { prijatelja, pro- } \\
\text { nalazak novih } \\
\text { prijatelja. }\end{array}$ & Mozaik knjiga \\
\hline $\begin{array}{l}\text { Nogomet za } \\
\text { pet - Sanja } \\
\text { Polak }\end{array}$ & $\begin{array}{l}\text { Humorističke } \\
\text { priče -- Hrvatska } \\
\text { književnost }\end{array}$ & 2018. & Roman & $\begin{array}{l}\text { Zgode i nezgode } \\
\text { petorice prijatelja } \\
\text { koji vole igrati } \\
\text { nogomet. }\end{array}$ & Mozaik knjiga \\
\hline $\begin{array}{l}\text { Ponoćni pu- } \\
\text { stolovi - Da- } \\
\text { vid Walliams }\end{array}$ & $\begin{array}{l}\text { Humoristički ro- } \\
\text { man -- Engleska } \\
\text { književnost }\end{array}$ & 2018. & Roman & $\begin{array}{l}\text { Pripovijest o } \\
\text { petero djece na } \\
\text { bolničkom odjelu } \\
\text { i njihovoj epskoj } \\
\text { pustolovini. Priča } \\
\text { o čaroliji, prija- } \\
\text { teljstvu i o ostva- } \\
\text { renju vlastitih } \\
\text { snova. }\end{array}$ & Mozaik knjiga \\
\hline $\begin{array}{l}\text { donFortnite: } \\
\text { vodič kroz } \\
\text { igru: } 100^{\star} \\
\text { neslužbeno - } \\
\text { Joe Bodler } \\
\end{array}$ & $\begin{array}{l}\text { Fortnite -- Ra- } \\
\text { čunalna igra } \\
\text {-- Vodič }\end{array}$ & 2018. & Vodič & $\begin{array}{l}\text { Osnove igre, } \\
\text { savjeti i tehnike } \\
\text { za igranje. }\end{array}$ & Egmont \\
\hline
\end{tabular}




\begin{tabular}{|c|c|c|c|c|c|}
\hline $\begin{array}{l}\text { Enciklope- } \\
\text { dija znanja } \\
\text { - ljudsko } \\
\text { tijelo - Marija } \\
\text { Perišić, Ruđer } \\
\text { Jeny }\end{array}$ & $\begin{array}{l}\text { Ljudsko tijelo } \\
\text { Enciklopedija } \\
\text { Enciklopedija za } \\
\text { mlade }\end{array}$ & 2018. & $\begin{array}{l}\text { Enciklo- } \\
\text { pedija }\end{array}$ & $\begin{array}{l}\text { Anatomija ljud- } \\
\text { skog tijela. }\end{array}$ & Znanje \\
\hline $\begin{array}{l}\text { Zabranjeno } \\
\text { kukanje - } \\
\text { Salvo Noe }\end{array}$ & $\begin{array}{l}\text { Pozitivno mišlje- } \\
\text { nje -- Trening } \\
\text { Trening asertiv- } \\
\text { nosti - Samoak- } \\
\text { tualizacija }\end{array}$ & 2018. & Priručnik & $\begin{array}{l}\text { Samopoštovanje i } \\
\text { motivacija. }\end{array}$ & Verbum \\
\hline $\begin{array}{l}\text { Igra na danski } \\
\text { način - Iben } \\
\text { Dissing San- } \\
\text { dahl }\end{array}$ & $\begin{array}{l}\text { Djeca -- Odgoj } \\
\text {-- Danska } \\
\text { Igra -- Odgojno- } \\
\text { obrazovni značaj }\end{array}$ & 2019. & $\begin{array}{l}\text { Praktičan } \\
\text { savjetnik }\end{array}$ & $\begin{array}{l}\text { Važnost igre u } \\
\text { odgoju djece. }\end{array}$ & Egmont \\
\hline
\end{tabular}

\subsection{Zaključak istraživanja}

$\mathrm{Na}$ temelju rezultata istraživanja te analize tematika knjiga za mlade u Hrvatskoj u razdoblju od 2016. do travnja 2019. moguće je donijeti zaključke kako slijedi: produkcija se knjiga za mlade iz godine u godinu povećava. Od ukupnog broja knjiga, knjige domaćih autora čine jednu trećinu dok su dvije trećine knjige stranih autora. Nakladnik koji je u promatranom razdoblju objavio najveći broj knjiga za mlade je Lumen izdavaštvo. Razlog je tome zasigurno taj što je Lumen izdavaštvo dio Školske knjige koji se bavi izdavanjem isključivo djela za djecu i mlade. Najveći je broj objavljenih knjiga u kojima prevladavaju mračne teme iz područja fantastike: borba dobra i zla, borbe čarobnjaka i vila, djelovanje likova u izmišljenim svjetovima, djelovanje magije, spašavanje ovog svijeta. Te teme isprepliću se s temama ljubavi, prijateljstva, rata, traženja identiteta. Zatim, vrlo je mnogo djela znanstvene fantastike u kojima se pojavljuju teme poput borbe naroda u izmišljenim galaksijama, budućnost svijeta, distopijski svjetovi, demonske sile, vanzemaljci, napredni roboti, mitologija; prisutni su i mitovi od kojih se spominju nordijski, ruski i slavenski, koristeći se likovima, mjestima i događajima iz poznatih mitskih priča. U knjigama koje pripadaju kategoriji kriminalističkih prevladavaju teme prijateljstva, rješavanje misterija, ljubav i manipulacija. U velikoj većini djela, iako im ljubav nije glavna tema, tu temu moguće je pronaći. U knjigama ljubavne tematike naglasak se najčešće stavlja na ljubavnu priču, govori se o problemima u ljubavi, prihvaćanju razlika među ljudima i obitelji. Zatim religijska djela koja su ispunjena životnim pričama vjernika, opisima sakramenata i korespondencijom. Nadalje, u povijesnim 
djelima najdominantnije su teme ratova, zatim veza među ljudima, trgovina, bolesti, religije te znanosti i tehnologije. Teme odrastanja, prijateljstva, ljubavi, škole, obitelji, vršnjaka, seksualnosti, interneta, nasilja, smrti, feminizma, mentalnog zdravlja i samopouzdanja prisutne su u psihološkim, društvenim te obiteljskim djelima. U knjigama hrvatskih autora prisutne su teme nasilja, ljubavnih problema, društvenih problema, prijateljstva i odrastanja. Djela takve suvremene tematike vrlo se često prevode sa stranog jezika, iako dominiraju knjige u kojima su prisutne različite teme koje pripadaju okviru fantastike i znanstvene fantastike. Ovo istraživanje obuhvatilo je sva djela koja su knjižnice i odabrani nakladnici kategorizirali kao knjige za mlade i objavljena su u navedenom razdoblju od tri godine i četiri mjeseca što zasigurno nisu sva djela za mlade objavljena u Hrvatskoj u tom razdoblju, ali svakako donosi vrijedne pokazatelje te kao takvo može poslužiti kao podloga i polazište budućim istraživanjima u području književnosti za mlade, informacijskim znanostima te u drugim područjima znanosti za slične teme.

\section{Zaključak}

Služeći se rezultatima provedenih istraživanja o čitateljskim ukusima i interesima mladih za čitanje iz užitka, može se zaključiti da se tematika prisutna u knjigama za mlade objavljenim u Hrvatskoj od 2016. do travnja 2019. uvelike podudara s čitateljskim ukusima i interesima mladih. Najviše je djela iz područja fantastike, a mladi se izjašnjavaju kako ih upravo ta tematika zanima. Dakle, zasigurno mnogo mladih uspijeva pronaći i čitati ono u čemu uživa. Međutim, podatak o tome da jako velik broj mladih ne uspijeva pronaći ono što voli i što ih zanima ukazuje na to da treba postojati i nastajati više djela drugačijih tema. Iako je u knjigama za mlade prisutno mnogo različitih tema, rezultati upućuju na to da mladi žele čitati o temama ljubavi i odrastanja prikazanim na pozitivan i svijetao način, te ona koja bi im pomogla u razrješavanju unutarnjih dvojbi te nekih problema, da ih zanimaju i avanturistička djela i, osobito djevojke, romantična djela. Tematika djela utječe na odabir knjige za čitanje iz užitka, a time na čitateljske navike. Za preporuku i savjetovanje mladih u čitanju, učitelji, profesori i knjižničari trebali bi istraživati i na individualnoj razini određivati kojim tipovima čitatelja mladi pripadaju. S druge strane, učitelji bi trebali pratiti aktualnu knjižnu produkciju za mlade da bi, osim onoga što se nastavnim programom propisuje, mogli preporučiti i ono u čemu će mladi uživati te na taj način poticati njihove čitateljske navike. 


\section{Literatura}

AskGfK. URL: https://www.askgfk.hr/index.php?id=7\&no_cache=1 (25. 9. 2019.).

Bamberger, Richard. 1975. Promoting the Reading Habit. Paris: UNESCO.

Breznitz, Zvia. 2006. Fluency in Reading: Synchronization of Processes. Mahwah, NJ: Lawrence Erlbaum and Associates.

Ciampa, Katia. 2016. Reading in the Digital Age: Using Electronic Books as a Teaching Tool for Beginning Readers. Canadian Journal of Learning and Technology 38, 2, 1-26.

Cunningham, Anne E., Stanovich, Keith E. 2001. What reading does for the mind. Journal of Direct Instruction 1, 2, 137-149.

Državni zavod za statistiku. Stanovništvo prema narodnosti i vjeri, popis 2011. URL: https://www.dzs.hr/Hrv/censuses/census2011/results/htm/H01_01_12/H01_01_12. html (29. 5. 2019.).

EACEA, 2011. Poučavanje čitanja u Europi: konteksti, politike i prakse. Bruxelles, Eurydice. URL: https://publications.europa.eu/hr/publication-detail/-/publication/cb8649340f5a-4984-bd56-51a8b9d44cfa/language-hr (17. 9. 2019.).

Furlan, Ivan. 1963. Čitanje u svjetlosti teorije informacije. Pedagogija 4, 596-612.

Gruić, Iva; Škuflić Horvat, Ines. 2016. Tabu teme u književnosti i kazalištu za djecu i mlade. U: Umjetnik kao pedagog pred izazovima suvremenog odgoja i obrazovanja: zbornik radova. Berislav Jerković i Tihana Škojo, ur. Osijek: Umjetnička akademija, 219-232.

Hopper, Rosemary. 2005. What are teenagers reading? Adolescent fiction reading habits and reading choices. Literacy (formerly Reading) 39, 3, 113-120.

Hrvatska enciklopedija. Avantura. Leksikografski zavod Miroslav Krleža, 2019. URL: http:// www.enciklopedija.hr/Natuknica.aspx?ID=4811 (29. 5. 2019.).

Kids and Family Reading Report. 2015. Scholastic/Yankelovich. URL: https://www.scholastic.com/content/dam/KFRR/InternationalReports/kfrruk.pdf (25. 9. 2019.).

Kotarac, Ines. 2011. Kultura čitanja: postoji lijek za bijeg od knjige. URL: http://www.dugirat. com/kultura/95-knjizevnost/12852-kultura-itanja-postoji-lijek-za-bijeg-od-knjige-v15-12852 (29. 5. 2019.).

Kutay, Veli. 2014. A survey of the reading habits of Turkish high school students and an examination of the efforts to encourage them to read (Unpublished Ph.D. thesis). University of Loughborough, United Kingdom. URL: https://dspace.lboro.ac.uk/dspace-jspui/bitstream/2134/15786/3/Thesis-2014-Kutay.pdf (29. 5. 2019.).

Leinenger M. (2014). Phonological coding during reading. Psychological bulletin, 140(6), 1534-1555. doi:10.1037/a0037830.

OECD. 2019. Reading performance (PISA) (indicator). URL: https://data.oecd.org/pisa/reading-performance-pisa.htm (29. 5. 2019.).

Peroš, Ivan. 2016. Čitateljski interesi i navike mladih u digitalnom dobu kao polazište za usluge narodnih knjižnica: diplomski rad. Zadar: Odjel za informacijske znanosti.

Pšihistal, Ružica. 2013. O književnosti kroz dimenziju čitanja/hranjenja. U: Čitanje za školu i život: IV. simpozij učitelja i nastavnika hrvatskoga jezika - Zbornik radova. Miro- 
slav Mićanović, ur. Zagreb: Agencija za odgoj i obrazovanje, 42-55. URL: https:// www.azoo.hr/citanje/Citanje.pdf (29. 5. 2019.).

Reading as a Perceptual Process. Alan Kennedy, Ralph Radach, Dieter Heller, Joël Pynte (ed.) (2010). Oxford: Elsevier Science Ltd.

Rončević Zubković, Barbara. 2013. Samoregulacija čitanja. U: Čitanje za školu i život: IV. simpozij učitelja i nastavnika hrvatskoga jezika - Zbornik radova. Miroslav Mićanović, ur. Zagreb: Agencija za odgoj i obrazovanje, 33-41.

Russell, David H. 1951. Reading as Communication. Childhood Education, 27, 6, 274-277.

Sabolović Krajina, Dijana. Čitateljske navike tinejdžera u Hrvatskoj. http://dzs.ffzg.unizg. hr/text/sabolovic-krajina_1993.htm (25. 9. 2019.).

Stričević, Ivanka, Jelušić, Srećko. 2010. Informacijske potrebe i čitateljski interesi građana Hrvatske. U: Knjiga i slobodno vrijeme: Međunarodni interdisciplinarni stručni Skup Knjiga i slobodno vrijeme zbornik radova. Elli Pecotić et al, ur. Split: Gradska knjižnica Marka Marulića Split, 16-32.

Stričević, Ivanka. 2005. Čitanje petnaestgodišnjaka - neki rezultati PISA projekta. U: Dijete $i$ društvo : časopis za promicanje prava djeteta, 6, 2, 391-393.

Težak, Dubravka. 1998. Tematske smjernice u svjetskoj književnosti za mladež. U: Odrastanje u zrcalu suvremene književnosti za djecu i mladež: zbornik radova. Ranka Javor, prir. Zagreb: Knjižnice grada Zagreba, 10-15.

Tomašević, Nives. 2008. Istraživanje stajališta o čitanju i njihov utjecaj na nakladništvo. $L i$ bellarium 1-2, 221-242.

Trupe, Alice. 2006. Thematic Guide to Young Adult Literature. London, Greenwood press.

Tveit, Ase Kristine. 2012. Reading habits and library use among young adults. Review of Children's Literature and Librarianship, 18, 2, 85-104.

Verhoeven, L., Reitsma, P., Siegel, L. S. 2011. Cognitive and linguistic factors in reading acquisition. Reading and writing, 24, 4, 387-394.

Visinko, Karol. 2008. O hrvatskoj književnosti za mladež. Kolo: časopis Matice hrvatske 18, 3-4.

Vodopija, Irena. 2004. Čitateljske navike, interesi i svjetonazor mladih. Problemi mladih Slavonije i Baranje: istraživanje. Ladislav Bognar [et al.], ur. Osijek: Filozofski fakultet, 111-119.

Walia, Paramjeet Kaur; Sinha, Nitu. 2014. Changing trend in reading habits of teenagers in Delhi: An impact assessment of demographic and environmental variables. Library Review, 63, 1/2, 125-137.

Zalar, Diana. 1998. Fantastika u suvremenom romanu za mladež. U: Odrastanje u zrcalu suvremene književnosti za mladež: zbornik. Ranka Javor, prir. Zagreb: Knjižnice grada Zagreba, 51-62.

Zima, Dubravka. 1998. Fantastika u suvremenoj hrvatskoj dječjoj prozi. U: Odrastanje u zrcalu suvremene književnosti za mladež. Ranka Javor, prir. Zagreb: Knjižnice grada Zagreba, 40-50.

Zima, Dubravka. 2008. Adolescentski roman u hrvatskoj književnosti do početka 2000. godine. Kolo 18, 3-4. URL: http://www.matica.hr/kolo/309/adolescentski-roman-u-hrvatskoj-knjizevnosti-do-pocetka-2000-godine-20528/ (29. 5. 2019.). 


\title{
ENJOYING READING: TOPICS IN YOUTH LITERATURE PUBLISHED IN CROATIA 2016 - 2019
}

\author{
Abstract \\ Ivana MARTINOVIĆ \\ Josip Juraj Strossmayer University of Osijek \\ Faculty of Humanities and Social Sciences \\ Lorenza Jägera 9, HR - 31000 Osijek, Croatia \\ imartinovic@ffos.hr \\ Ivona GRGIĆ \\ Josip Juraj Strossmayer University of Osijek \\ Faculty of Humanities and Social Sciences \\ Lorenza Jägera 9, HR - 31000 Osijek, Croatia \\ igrgic@ffos.hr \\ Elizabeta KOTROMANOVIĆ \\ Josip Juraj Strossmayer University of Osijek \\ Faculty of Humanities and Social Sciences \\ Lorenza Jägera 9, HR - 31000 Osijek, Croatia \\ ekotromanovic@ffos.hr
}

This paper consists of a theoretical and empirical part. The theoretical part primarily focuses its attention on the purpose of reading, then discusses the results that the youth from Croatia achieve in international literacy studies and the possible causes of the lack of reading for pleasure among youth. Furthermore, the motives, interests and habits of young people are discussed based on the results of previous research. The authors take the view that the subject of the book is one of the factors that can stimulate and motivate young people to read. The paper further provides an overview of the topics that appear in books intended for young people published from the 60s of the 20th century onwards. The empirical part of the paper presents the results of the research conducted by a combination of different methodological procedures; creating a book list and analyzing the content, with the aim of determining the topics that appear in the books for young people published in Croatia from 2016 to April 2019. The conclusion of the research part of the paper is primarily focused on the topics that are present in the books for youth. The conclusion at the end of the paper brings together insight on the topics of the books for young people and knowledge gained from previous research 
and theoretical knowledge on reading topics, as well as the tastes, habits and interests of young people to read for pleasure and the role of topics of books in motivating young people for this type of reading.

Keywords: reading for pleasure, books for young people, young people, topics in books for youth, Croatia 